\title{
Multi-year chemical composition of the fine-aerosol fraction in Athens, Greece, with emphasis on the contribution of residential heating in wintertime
}

\author{
Christina Theodosi ${ }^{1,2, *}$, Maria Tsagkaraki ${ }^{1}$, Pavlos Zarmpas ${ }^{1}$, Georgios Grivas ${ }^{2}$, Eleni Liakakou ${ }^{2}$, \\ Despina Paraskevopoulou $^{2}$, Maria Lianou ${ }^{2}$, Evangelos Gerasopoulos ${ }^{2}$, and Nikolaos Mihalopoulos ${ }^{1,2}$ \\ ${ }^{1}$ Environmental Chemical Processes Laboratory (ECPL), University of Crete, Heraklion, Crete, 71003, Greece \\ ${ }^{2}$ Institute for Environmental Research and Sustainable Development (IERSD), National Observatory of Athens, \\ P. Penteli, Athens, 15236, Greece \\ * Invited contribution by Christina Theodosi, recipient of the EGU Atmospheric Sciences Outstanding Student \\ Poster Award 2016.
}

Correspondence: Nikolaos Mihalopoulos (mihalo@uoc.gr) and Christina Theodosi (c_theodosi@chemistry.uoc.gr)

Received: 12 February 2018 - Discussion started: 27 March 2018

Revised: 13 September 2018 - Accepted: 17 September 2018 - Published: 9 October 2018

\begin{abstract}
In an attempt to take effective action towards mitigating pollution episodes in Athens, precise knowledge of $\mathrm{PM}_{2.5}$ composition and its sources is a prerequisite. Thus, a 2-year chemical composition dataset from aerosol samples collected in an urban background site in central Athens from December 2013 to March 2016 has been obtained and a positive matrix factorization (PMF) was applied in order to identify and apportion fine aerosols to their sources. A total of 850 aerosol samples were collected on a 12 to $24 \mathrm{~h}$ basis and analyzed for major ions, trace elements, and organic and elemental carbon, allowing us to further assess the impact of residential heating as a source of air pollution over Athens.

The ionic and carbonaceous components were found to constitute the major fraction of the $\mathrm{PM}_{2.5}$ aerosol mass. The annual contribution of the ion mass (IM), particulate organic mass (POM), dust, elemental carbon (EC), and sea salt (SS) was calculated at $31 \%, 38 \%, 18 \%, 8 \%$, and $3 \%$, respectively, and exhibited considerable seasonal variation. In winter, the share of IM was estimated down to $23 \%$, with $\mathrm{POM}+\mathrm{EC}$ being the dominant component accounting for $52 \%$ of the $\mathrm{PM}_{2.5}$ mass, while in summer, IM (42\%) and carbonaceous aerosols (41\%) contributed almost equally.

Results from samples collected on a $12 \mathrm{~h}$ basis (day and night) during the three intensive winter campaigns indicated the impact of heating on the levels of a series of compounds. Indeed, $\mathrm{PM}_{2.5}, \mathrm{EC}, \mathrm{POM}, \mathrm{NO}_{3}^{-}, \mathrm{C}_{2} \mathrm{O}_{4}^{2-}$, non sea salt (nss) $\mathrm{K}^{+}$and selected trace metals including $\mathrm{Cd}$ and
\end{abstract}

$\mathrm{Pb}$ were increased by up to a factor of 4 in the night compared to the day, highlighting the importance of heating on air quality in Athens. Furthermore, in order to better characterize wintertime aerosol sources and quantify the impact of biomass burning on $\mathrm{PM}_{2.5}$ levels, source apportionment was performed. The data can be interpreted on the basis of six sources, namely biomass burning (31\%), vehicular emissions $(19 \%)$, heavy oil combustion $(7 \%)$, regional secondary $(21 \%)$, marine aerosols $(9 \%)$, and dust particles $(8 \%)$. Regarding night-to-day patterns their contributions shifted from $19 \%, 19 \%, 8 \%, 31 \%, 12 \%$, and $10 \%$ of the $\mathrm{PM}_{2.5}$ mass during day to $39 \%, 19 \%, 6 \%, 14 \%, 7 \%$, and $7 \%$ during the night, underlining the significance of biomass burning as the main contributor to fine particle levels during nighttime in winter.

\section{Introduction}

The scientific interest in aerosols has widely increased during the last decades due to their impact on air quality, human health, and climate change (e.g., Seinfeld and Pandis, 1998). Legislation regarding atmospheric particulate matter is gradually becoming more stringent as a result of the frequent episodes encountered on regional or even continental scales also associated with synoptic and mesoscale meteorological conditions (Querol et al., 2009). Hence, significant efforts are 
targeted towards improving air quality through emission reduction measures (Daskalakis et al., 2016).

Particles with diameter of $2.5 \mu \mathrm{m}$ or less are of particular interest due to the fact that they contribute significantly to detrimental health effects (Dockery and Pope, 1994; Ostro et al., 2006), penetrating the cell membranes more efficiently (Salma et al., 2002; Li et al., 2003; Bell et al., 2009) and acting as carriers of toxic and carcinogenic components (Beddows et al., 2004). Recent epidemiological studies have highlighted the risk of exposure to enhanced levels of carbonaceous aerosols, revealing notable associations with cardiovascular mortality and morbidity (Ostro et al., 2010; Lipsett et al., 2011; Krall et al., 2013). Trace metals are also related to chronic and acute health problems due to their toxicity (Pope III et al., 2002; Stiebet et al., 2002).

In Greece, air quality has improved since the advent of the global economic recession in 2008 due to the abrupt cut down of anthropogenic sources such as traffic and industrial activities (Vrekoussis et al., 2013; Gratsea et al., 2017). However, since winter 2011-2012, the extensive use of wood as fuel for residential heating appears to have changed this decreasing trend, at least for the winter period (e.g., Gratsea et al., 2017). Burning wood in residential stoves (and fireplaces) is an important source of directly emitted fine particulate matter $\left(\mathrm{PM}_{2.5}\right), \mathrm{EC}$, and polycyclic aromatic hydrocarbons (PAH), with a great impact on air quality (EEA, 2013, 2014). Paraskevopoulou et al. (2015) have shown that at a suburban site (Penteli) in the greater Athens area, the contribution of particulate organic matter (POM) to the additional local aerosol mass increased by $30 \%$ between winter 2012 and winter 2013. Fourtziou et al. (2017) have reported on several wood burning tracers monitored during winter 20132014, linking them to the presence of severe smog events due to wood combustion for residential heating.

Informed decision-making concerning the improvement of air quality demands precise knowledge of PM chemical speciation and source attribution. Based on the effect of finer particles on health and their association with urban sources, in contrast to natural aerosols, it is even more important to focus such analyses on fine-aerosol fractions. In this study, $\mathrm{PM}_{2.5}$ was chemically characterized for inorganic species, such as trace elements and water-soluble ions, as well as for carbonaceous components, such as organic and elemental carbon. To our knowledge, this is the first time that such a long-term, uninterrupted estimation of the chemical composition of $\mathrm{PM}_{2.5}$, a chemical mass closure exercise and source identification of particulate matter, took place in parallel at an environment in southeastern Europe that offers challenging conditions in terms of pollution contributors and timing (recession period). Given the intensive use of wood as fuel for residential heating since winter 2012 in Athens, the current work was focused on winter periods. In order to highlight the impact of nighttime winter PM sources on the air quality of urban Athens, aerosol sampling was intensified from rou- tine $24 \mathrm{~h}$ time resolution to $12 \mathrm{~h}$ resolution during the three consecutive winters (2013-2014 to 2015-2016).

\section{Experimental}

\subsection{Sampling site}

Aerosol sampling was conducted at the central premises of the National Observatory of Athens situated on a small hill (110 m a.s.1.), in downtown Athens (Thissio; $38^{\circ} 0.00^{\prime} \mathrm{N}$, $\left.23^{\circ} 43.48^{\prime} \mathrm{E}\right)$. This urban background site is not directly impacted by local human activities, as it is surrounded mostly by a pedestrian zone and moderately populated neighborhoods. Therefore, the site could be considered representative of the exposure of the majority of population in the Greek capital, as demonstrated by Gratsea et al. (2017).

\subsection{Sampling and chemical analyses}

$\mathrm{PM}_{2.5}$ aerosol was collected on Quartz fiber filters (Flex Tissuquartz, 2500QAT-UP $47 \mathrm{~mm}$, Pall) with a Dichotomous Partisol Sampler 2025 (Rupprecht \& Patashnick, 16.7 $\mathrm{L} \mathrm{min}^{-1}$ ) on a daily basis during a period of more than 2 years (December 2013-March 2016). During the three winter periods (from December to February), the sampling frequency was changed to $12 \mathrm{~h}$ in an attempt to study the characteristics of emissions from heating activities in depth, resulting in a collection of 447 filters out of the total of 848 . The $\mathrm{PM}_{2.5}$ aerosol mass was gravimetrically determined (samples were conditioned pre- and post-sampling at $20 \pm 3{ }^{\circ} \mathrm{C}$ and $45 \pm 5 \% \mathrm{RH}$ for $48 \mathrm{~h}$ ) using a microbalance (Fourtziou et al., 2017; Paraskevopoulou et al., 2014), and filters were stored until the chemical analysis. Filter blanks and blank field samples were also prepared and analyzed. All $\mathrm{PM}_{2.5}$ samples were analyzed for organic carbon (OC) and elemental carbon (EC), water-soluble ions $\left(\mathrm{Cl}^{-}, \mathrm{Br}^{-}, \mathrm{NO}_{3}^{-}, \mathrm{HPO}_{4}^{2-}, \mathrm{SO}_{4}^{2-}\right.$, $\mathrm{C}_{2} \mathrm{O}_{4}^{2-}, \mathrm{Na}^{+}, \mathrm{NH}_{4}^{+}, \mathrm{K}^{+}, \mathrm{Mg}^{2+}$, and $\mathrm{Ca}^{2+}$ ), elements of a crustal origin $(\mathrm{Al}, \mathrm{Fe}$, and $\mathrm{Ca})$ and trace elements $(\mathrm{Zn}, \mathrm{Pb}$, $\mathrm{Cu}, \mathrm{Ni}, \mathrm{V}, \mathrm{Cr}, \mathrm{Mn}, \mathrm{Cd}$, and $\mathrm{As}$ ). All reported concentrations were corrected for blanks. The chemical speciation data were utilized to perform a chemical mass closure exercise and chemometric receptor modeling for source apportionment.

Filters were analyzed for the carbonaceous components with the thermal-optical transmission (TOT) technique (Birch and Cary, 1996) and while using a Sunset Laboratory OC/EC Analyzer, as described in detail by Theodosi et al. (2010a) and Paraskevopoulou et al. (2014), applying the EUSAAR-2 protocol (Cavalli et al., 2010).

Filter parts were analyzed by ion chromatography (IC) for the determination of the main ionic species mentioned above, as described by Paraskevopoulou et al. (2014).

An acid microwave digestion procedure, followed by inductively coupled plasma optical emission spectrometry (ICP-OES, Thermo Electron ICAP 6000 Series), was ap- 
plied for the determination of major and trace metal concentrations during this long-term sampling period $(n=848)$, following the procedure described in detail by Theodosi et al. (2010b). All 12 elements were also determined by inductively coupled plasma mass spectrometry (ICP-MS, Perkin Elmer, NexION 300X) for all winter (December-February) and summer (June-August) samples $(n=592)$. Results reported hereafter for $\mathrm{Al}, \mathrm{Ca}, \mathrm{Mn}, \mathrm{Fe}, \mathrm{V}, \mathrm{Cr}, \mathrm{Ni}, \mathrm{Cu}$, and $\mathrm{Zn}$ correspond to the ICP-OES analysis, while $\mathrm{Cd}, \mathrm{As}$, and $\mathrm{Pb}$ correspond to ICP-MS.

Hourly meteorological data on horizontal wind velocity and direction from NOA's station at Thissio were additionally retrieved.

\subsection{Source apportionment}

In order to identify major wintertime sources of $\mathrm{PM}_{2.5}$ and their day-night patterns, positive matrix factorization (PMF) receptor modeling was performed on the $12 \mathrm{~h}$ winter chemical composition data.

In the PMF factor analytic model, speciated sample data are decomposed into matrices of factor contributions and factor profiles. The matrix elements are obtained through the minimization of weighted decomposition residuals (object function $-Q$ ) in an iterative process. Uncertainties associated with the analysis of individual species are used for weighting. In the present case, the multilinear engine (ME-2) program was used for solving the PMF problem in the setting of the EPA PMF5.0 software.

Uncertainties per species and sample were calculated (Reff et al., 2007) based on the error fraction of the measurement and the method detection limit for each component.

Values equal to five-sixths of the detection limit were assigned as uncertain for samples below detection limits (BDL). Missing data points were substituted by the geometric mean of the respective species concentrations and given 4 times this value as uncertainty.

In total, 22 analyzed species were considered. Additionally, the insoluble fraction of $\mathrm{Ca}$ (Ca-ins) was also incorporated in the PMF analysis through subtraction of ionic $\mathrm{Ca}^{2+}$ from the Ca determined by ICP-OES (Beuck et al., 2011; Yubero et al., 2011).

$\mathrm{PM}_{2.5}$ was set as a total variable and had its uncertainty tripled so that it would not overly influence solutions. The PMF analysis was performed on the day and night dataset to obtain the source profiles, and the day and night contributions to $\mathrm{PM}_{2.5}$ were calculated separately (Bernardoni et al., 2011; Canha et al., 2014). Supplementary PMF source apportionment was conducted for the 2-year period March 2014February 2016, using the daily mean concentration and uncertainty data.

Solutions involving 4-10 sources were examined, and the ratios of actual (robust) to expected values of $Q\left(Q_{\mathrm{R}} / Q_{\mathrm{EXP}}\right)$ were recorded. The selected solution, which was obtained for six factors, was physically interpretable, and the reduction of

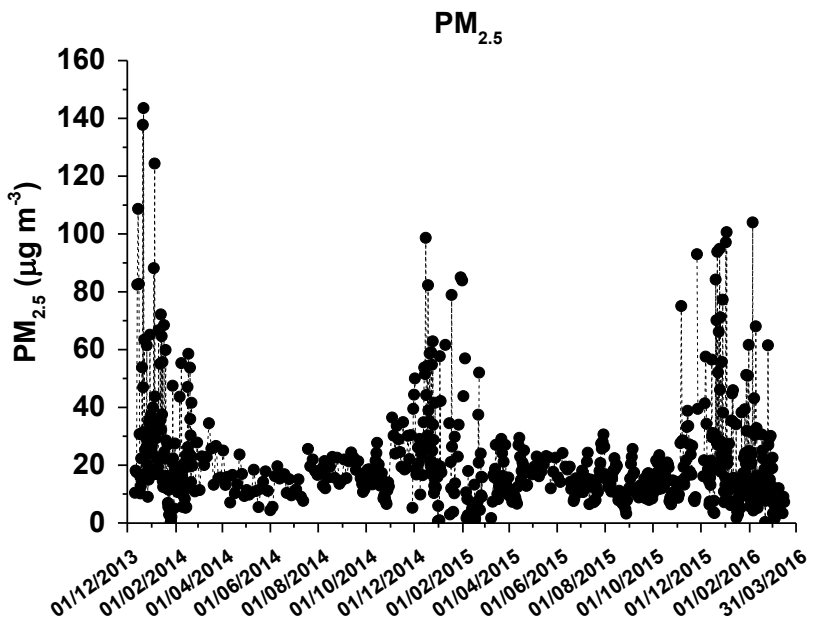

Figure 1. Daily $\mathrm{PM}_{2.5}$ mass concentrations $\left(\mu \mathrm{g} \mathrm{m}^{-3}\right)$ at Thissio station for the studied period from December 2013 to March 2016.

the $Q_{\mathrm{R}} / Q_{\mathrm{EXP}}$ for solutions with a greater number of factors was small, indicating that new factors were not introducing additional information (Brown et al., 2015). The impact of small-medium scale atmospheric circulation has also been taken into account by examining associations between source contributions and wind direction and velocity. Bivariate conditional probability function (CPF) calculations and graphical interpolation in polar coordinates have been performed according to the methodology developed by Uria-Tellaitxe and Carslaw (2014). The stability of the obtained solution against random sampling errors and rotational ambiguity was assessed using the BS-DISP procedure of the Environmental Protection Agency (EPA) PMF 5.0 (Paatero et al., 2014). More details on PMF model parameters and BS-DISP results are reported in the Supplement.

\section{Results and discussion}

\section{1 $\quad \mathbf{P M}_{2.5}$ levels}

The daily $\mathrm{PM}_{2.5}$ mass concentration at the urban background site of Thissio from all 12 and $24 \mathrm{~h}$ samples varied significantly from 1 to $144 \mu \mathrm{g} \mathrm{m}^{-3}$, with higher concentrations occurring in the winter (mean: $27.4 \pm 8.7 \mu \mathrm{g} \mathrm{m}^{-3}$; median: $27.5 \mu \mathrm{g} \mathrm{m}^{-3}$ ) and lower concentrations in the summer (mean: $14.7 \pm 1.2 \mu \mathrm{g} \mathrm{m}^{-3}$; median: $15.0 \mu \mathrm{g} \mathrm{m}^{-3}$ ) (Fig. 1).

The annual mean $\mathrm{PM}_{2.5}$ concentrations of the 2 complete years of the study period (2014 and 2015) based on daily values were equal to $22.7 \pm 16.4$ (median: $18.0 \mu^{-3} \mathrm{~m}^{-3}$ ) and $19.3 \pm 16.1 \mu \mathrm{g} \mathrm{m}^{-3}$ (median: $15.2 \mu \mathrm{g} \mathrm{m}^{-3}$ ), respectively, both being lower than the annual $\mathrm{PM}_{2.5}$ limit imposed by the EU Ambient Air Quality Directive (2008/50/EC), which is set at $25 \mu \mathrm{g} \mathrm{m}^{-3}$. 
(a)

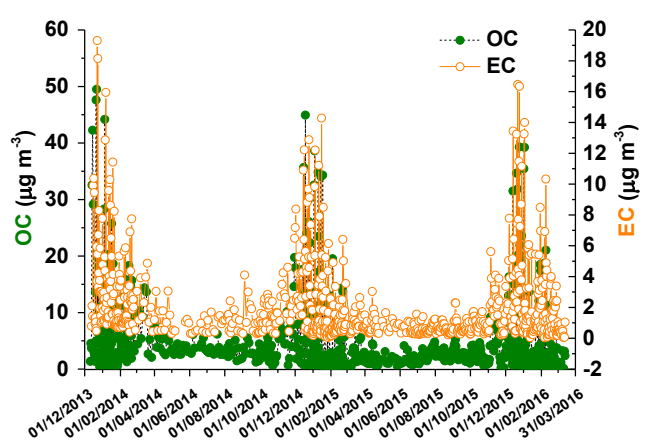

(c)

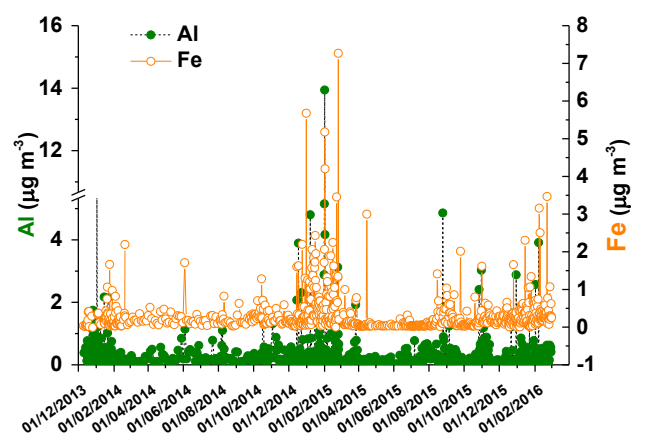

(e)

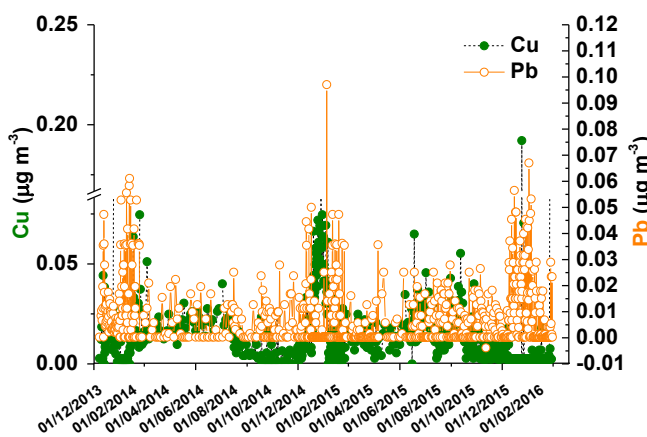

(b)

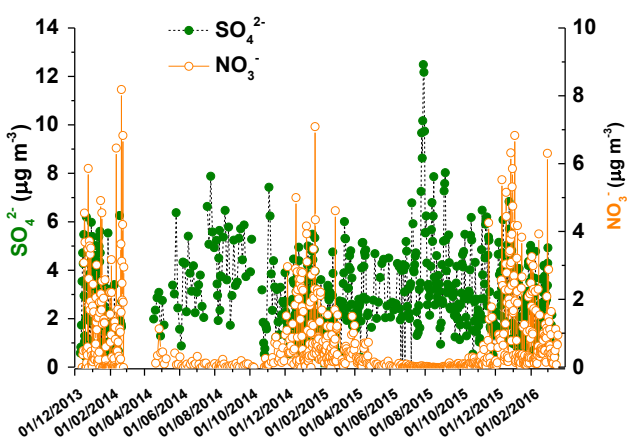

(d)

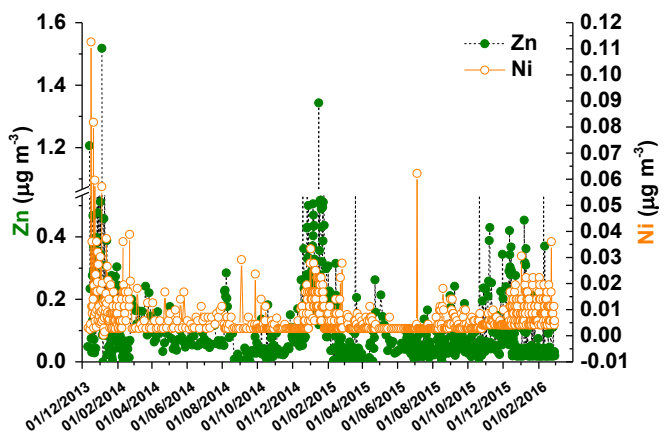

(f)

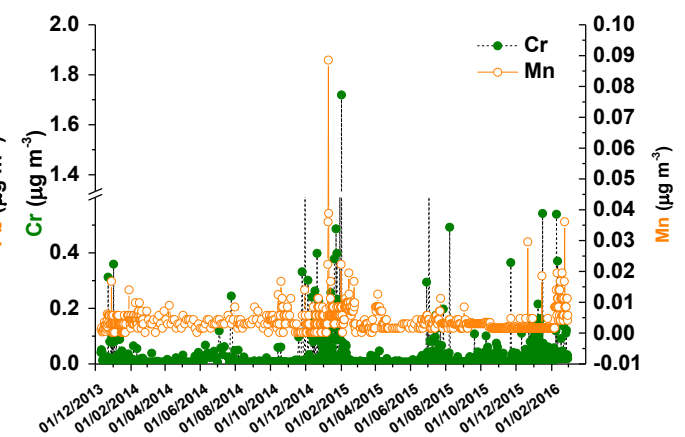

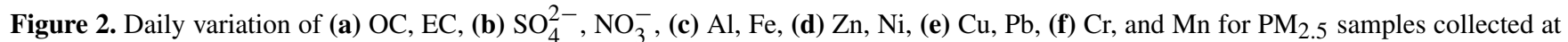
Thissio for the sampling period December 2013-March 2016.

The $\mathrm{PM}_{2.5}$ values reported here are in good agreement with those reported in other urban environment studies for Athens (18-26 $\mathrm{g} \mathrm{m}^{-3}$, Theodosi et al., 2011; Mantas et al., 2014, Paraskevopoulou et al., 2015) or other European cities (15-30 $\mathrm{gg} \mathrm{m}^{-3}$, Putaud et al., 2010; Amato et al., 2016).

\section{2 $\mathbf{P M}_{2.5}$ chemical composition}

\subsubsection{Carbonaceous components}

Figure $2 \mathrm{a}$ represents the time series of the daily concentration levels of $\mathrm{OC}$, which ranged from below DL to
$49.5 \mu \mathrm{g} \mathrm{m}^{-3}$ (mean: $4.0 \pm 2.0 \mu \mathrm{g} \mathrm{m}^{-3}$; median: $3.1 \mu \mathrm{g} \mathrm{m}^{-3}$; Table 1), and of EC, from below DL to $19.3 \mu \mathrm{g} \mathrm{m}^{-3}$ (mean: $1.5 \pm 1.0 \mu \mathrm{g} \mathrm{m}^{-3}$; median: $1.1 \mu \mathrm{g} \mathrm{m}^{-3}$ ). Both carbonaceous components exhibited a distinct seasonal variability, with lower mean concentrations during summer, to the order of $2.9 \pm 0.1 \mu \mathrm{g} \mathrm{m}^{-3}$ (median: $2.9 \mu \mathrm{g} \mathrm{m}^{-3}$ ) and $0.7 \pm 0.1 \mu \mathrm{g} \mathrm{m}^{-3}$ (median: $0.8 \mu \mathrm{g} \mathrm{m}^{-3}$ ) for $\mathrm{OC}$ and $\mathrm{EC}$, respectively. Mean winter values were higher and equal to $6.3 \pm 2.9 \mathrm{\mu g} \mathrm{m}^{-3}$ (median: $5.8 \mu \mathrm{g} \mathrm{m}^{-3}$ ) and $2.8 \pm 1.2 \mu \mathrm{g} \mathrm{m}^{-3}$ (median: $2.6 \mu \mathrm{g} \mathrm{m}^{-3}$ ), respectively. 
Table 1. Mean, standard deviation, median, and range of measured concentrations for $\mathrm{PM}_{2.5}$ aerosol samples, collected at Thissio and other urban sites in Athens. Values for $\mathrm{PM}_{2,5}, \mathrm{OC}$, and EC are in $\mu \mathrm{g} \mathrm{m}^{-3}$, whereas for the rest of the species, they are in $\mathrm{ng} \mathrm{m}^{-3}$.

\begin{tabular}{|c|c|c|c|c|c|c|c|}
\hline \multirow[t]{2}{*}{$n g m^{-3}$} & \multicolumn{2}{|c|}{$\mathrm{PM}_{2.5}$} & \multicolumn{2}{|c|}{$\mathrm{PM}_{2.5}$} & \multirow{2}{*}{$\frac{\mathrm{PM}_{2.5}}{\text { Summer and winter mean }}$} & \multirow{2}{*}{$\begin{array}{c}\mathrm{PM}_{2.5} \\
\text { Mean } \pm \mathrm{SD}\end{array}$} & \multirow{2}{*}{$\begin{array}{c}\mathrm{PM}_{2.5} \\
\text { Mean } \pm \mathrm{SD}\end{array}$} \\
\hline & Mean & Median & Mean & range & & & \\
\hline Sampling & \multicolumn{2}{|c|}{$\begin{array}{c}\text { Dec 2013-Mar } 2016 \\
(n=850)\end{array}$} & \multicolumn{2}{|c|}{$\begin{array}{l}\text { Summer } 1987 \\
\quad(n=27)\end{array}$} & $\begin{array}{l}\text { Summer } 1982 \text { and winter } \\
1982-1983(n=29)\end{array}$ & $\begin{array}{l}\text { Sep 2005-Aug } 2006 \\
(n=109)\end{array}$ & $\begin{array}{c}\text { Four short-term } \\
\text { seasonal campaigns } \\
\text { Jun } 2011-\text { Feb } 2013 \\
\quad(n=211)\end{array}$ \\
\hline Location & \multicolumn{2}{|c|}{ Athens urban } & \multicolumn{2}{|c|}{ Athens urban } & Athens urban & Athens urban & Athens urban \\
\hline Reference & \multicolumn{2}{|c|}{ This study } & \multicolumn{2}{|c|}{$\begin{array}{c}\text { Scheff and } \\
\text { Valiozis (1990) }\end{array}$} & $\begin{array}{l}\text { Valaoras et } \\
\text { al. (1988) }\end{array}$ & $\begin{array}{l}\text { Theodosi et } \\
\text { al. (2011) }\end{array}$ & $\begin{array}{l}\text { Paraskevopoulou } \\
\text { et al. (2015) }\end{array}$ \\
\hline $\mathrm{PM}_{2.5}$ & $19.1 \pm 7.1$ & 15.5 & 80.7 & $27-127$ & & $29.4 \pm 10.3$ & $33 \pm 12$ \\
\hline $\mathrm{OC}$ & $4.0 \pm 2.0$ & 3.12 & 16.9 & $5.7-43.4$ & $25.7 / 16.1$ & - & $5.55 \pm 2.01$ \\
\hline EC & $1.5 \pm 1.0$ & 1.12 & 4.2 & $1.2-18.6$ & $8.20 / 11.0$ & - & $2.06 \pm 0.78$ \\
\hline $\mathrm{Cl}^{-}$ & $272 \pm 197$ & 155 & 350 & 0-1300 & $75 / 440$ & 490 & $182 \pm 80.2$ \\
\hline $\mathrm{Br}^{-}$ & $19.4 \pm 10.7$ & 14.2 & 130 & 0-589 & $140 / 380$ & - & - \\
\hline $\mathrm{NO}_{3}^{-}$ & $476 \pm 377$ & 278 & 2000 & $500-5100$ & - & 1090 & $896 \pm 634$ \\
\hline $\mathrm{HPO}_{4}^{2-}$ & $54.3 \pm 37.4$ & 46.4 & - & - & - & - & $72.9 \pm 73.6$ \\
\hline $\mathrm{SO}_{4}^{2-}$ & $3033 \pm 835$ & 2933 & 10400 & $4100-23700$ & - & 5790 & $3293 \pm 1473$ \\
\hline $\mathrm{C}_{2} \mathrm{O}_{4}^{2-}$ & $143 \pm 56$ & 123 & - & - & - & 320 & $203 \pm 50.4$ \\
\hline $\mathrm{Na}^{+}{ }^{4}$ & $307 \pm 196$ & 369 & 369 & $0-1890$ & - & 830 & $255 \pm 78.7$ \\
\hline $\mathrm{NH}_{4}^{+}$ & $1422 \pm 685$ & 1112 & - & - & - & 920 & $843 \pm 433$ \\
\hline $\mathrm{K}^{+}$ & $273 \pm 109$ & 268 & 428 & $24.2-833$ & $160 / 380^{* *}$ & 460 & $150 \pm 76.7$ \\
\hline $\mathrm{Mg}^{2+}$ & $64.0 \pm 31.6$ & 60.7 & 132 & $0-653$ & - & 50 & $8.84 \pm 10.9$ \\
\hline $\mathrm{Ca}^{2+}$ & $160 \pm 127$ & 113 & - & - & - & 320 & $219 \pm 246$ \\
\hline $\mathrm{Al}$ & $293 \pm 106$ & 263 & 408 & - & $130 / 850$ & - & $494 \pm 95.3$ \\
\hline As & $1.9 \pm 0.2$ & 1.83 & - & - & $34 / 13$ & - & $4.35 \pm 5.56$ \\
\hline $\mathrm{Ca}$ & $745 \pm 522$ & 501 & 2610 & $776-4970$ & - & - & $898 \pm 254$ \\
\hline $\mathrm{Cd}$ & $1.7 \pm 0.7$ & 1.75 & 220 & 0-1141 & - & - & $1.16 \pm 0.60$ \\
\hline $\mathrm{Cr}$ & $27.1 \pm 20.4$ & 19.6 & - & - & - & - & $18.8 \pm 6.29$ \\
\hline $\mathrm{Cu}$ & $14.8 \pm 5.2$ & 16.2 & 50.6 & $0-143$ & $35 / 260$ & - & $17.4 \pm 5.75$ \\
\hline $\mathrm{Fe}$ & $264 \pm 125$ & 234 & 1100 & 293-1990 & $490 / 300$ & - & $304 \pm 110$ \\
\hline V & $6.9 \pm 2.4$ & 6.61 & - & - & $-/ 6.60$ & - & $7.79 \pm 3.86$ \\
\hline $\mathrm{Zn}$ & $93.0 \pm 50.1$ & 73.1 & 273 & $46.8-615$ & $130 / 210$ & - & $94.9 \pm 34.8$ \\
\hline $\mathrm{Mn}$ & $4.6 \pm 1.4$ & 5.06 & 21.6 & 0-70.3 & $-/ 14.0$ & - & $5.68 \pm 1.23$ \\
\hline $\mathrm{Ni}$ & $6.0 \pm 2.6$ & 4.86 & 11.6 & $0-37.4$ & $21.0 / 8.60$ & - & $5.16 \pm 2.41$ \\
\hline $\mathrm{Pb}$ & $4.1 \pm 3.4$ & 3.68 & 699 & $162-2273$ & $610 / 1100$ & - & $12.5 \pm 2.46$ \\
\hline
\end{tabular}

OC and EC concentrations fall within the range reported for background urban sites across Europe (Barcelona, Florence, and Milan; Amato et al., 2016; OC $=2.4-$ $6.5 \mu \mathrm{g} \mathrm{m}^{-3}$ and $\mathrm{EC}=0.9-1.8 \mu \mathrm{g} \mathrm{m}^{-3}$ ). Their levels are higher than those reported for a remote background site in Crete, Greece (Koulouri et al., 2008; OC $=1.8 \pm$ $1.4 \mu \mathrm{g} \mathrm{m}^{-3}$ and $\mathrm{EC}=0.27 \pm 0.18 \mu \mathrm{g} \mathrm{m}^{-3}$ ), and a suburban site in Athens (Remoundaki et al., 2013; OC $=2.4 \mu \mathrm{g} \mathrm{m}^{-3}$ and $\mathrm{EC}=1.0 \mu \mathrm{g} \mathrm{m}^{-3}$ ), while they were significantly lower than those previously reported for megacities such as Istanbul (Theodosi et al., 2010a; OC $=6.6 \mu \mathrm{g} \mathrm{m}^{-3}$ and $\left.\mathrm{EC}=2.9 \mu \mathrm{g} \mathrm{m}^{-3}\right)$.

\subsubsection{Ionic Composition}

$\mathrm{SO}_{4}^{2-}$ was the main ion contributor to the fine-aerosol mass, accounting for $16 \%$ (mean: $3.0 \pm 0.8 \mu \mathrm{g} \mathrm{m}^{-3}$; median: $2.9 \mu \mathrm{g} \mathrm{m}^{-3}$ ), while $\mathrm{NH}_{4}^{+}$and $\mathrm{NO}_{3}^{-}$followed with contributions of $7 \%$ (mean: $1.4 \pm 0.7 \mu \mathrm{g} \mathrm{m}^{-3}$; median: $1.1 \mu \mathrm{g} \mathrm{m}^{-3}$ ) and $2 \%$ (mean: $0.5 \pm 0.4 \mu \mathrm{g} \mathrm{m}^{-3}$; median: $0.3 \mu \mathrm{g} \mathrm{m}^{-3}$ ), respectively. Figure $2 \mathrm{~b}$ represents the daily variation of $\mathrm{SO}_{4}^{2-}$ and $\mathrm{NO}_{3}^{-}$, while Table 1 provides the annual levels of all the examined ions.

The mean $\mathrm{SO}_{4}^{-2}$ concentration for the whole study period (December 2013-March 2016) is in close agreement with the value $\left(3.1 \pm 0.8 \mu \mathrm{g} \mathrm{m}^{-3}\right)$ reported from the 5year (May 2008-April 2013) study of Paraskevopoulou et al. (2015) for the suburban station of Penteli and also with 
other recent studies performed in Athens (e.g., Mantas et al., 2014). Notably, a substantial decrease is apparent in comparison to the levels recorded during the previous decade in the area (Karageorgos and Rapsomanikis, 2010; Theodosi et al., 2011). The annual measured levels of $\mathrm{NO}_{3}^{-}$at Thissio are significantly higher than those reported for suburban and background locations in Greece, while for $\mathrm{NH}_{4}^{+}$, they are comparable (e.g., Mantas et al., 2014; Paraskevopoulou et al., 2015), highlighting the respective roles of local $\left(\mathrm{NO}_{3}^{-}\right)$ and regional $\left(\mathrm{NH}_{4}^{+}\right.$; see below) contributing sources.

Several other water-soluble ions were also identified such as $\mathrm{Cl}^{-}, \mathrm{Br}^{-}, \mathrm{HPO}_{4}^{2-}, \mathrm{C}_{2} \mathrm{O}_{4}^{2-}, \mathrm{Na}^{+}, \mathrm{K}^{+}, \mathrm{Mg}^{2+}$, and $\mathrm{Ca}^{2+}$. Annual means (Table 1) ranged between $19.4 \mathrm{ng} \mathrm{m}^{-3} \mathrm{for}^{-}$ (median: $14.2 \mathrm{ng} \mathrm{m}^{-3}$ ) to $307 \pm 196 \mathrm{ng} \mathrm{m}^{-3}$ for $\mathrm{Na}^{+}$(median: $369 \mathrm{ng} \mathrm{m}^{-3}$ ). All annual mean concentrations of these ions are in the same range as those reported for $\mathrm{PM}_{2.5}$ in Athens (Theodosi et al., 2011; Pateraki et al., 2012; Remoundaki et al., 2013; Paraskevopoulou et al., 2015).

\subsubsection{Trace metals}

Table 1 summarizes the mean annual concentrations of elements and trace metals during the sampling period, and Fig. $2 c-f$ represent the daily variation of several representative metals. The mean annual concentrations of elements of a crustal origin such as $\mathrm{Al}$ and elements of a mixed origin that still have a significant crustal component, such as $\mathrm{Fe}$ and $\mathrm{Ca}$, vary from 0.26 to $0.75 \mu \mathrm{g} \mathrm{m}^{-3}$ (Table 1 ). The mean annual values for elements of a major anthropogenic origin (Mn, V, $\mathrm{Cr}, \mathrm{Cd}, \mathrm{Ni}, \mathrm{Cu}, \mathrm{As}$, and $\mathrm{Pb}$ ) are generally very low, varying from 1.7 to $27.1 \mathrm{ng} \mathrm{m}^{-3}$. On a monthly basis, the concentrations of toxic metals originating from human activities, such as $\mathrm{As}, \mathrm{Cd}$, and $\mathrm{Ni}$, which are mainly confined in the $\mathrm{PM}_{2.5}$ fraction (Koulouri et al., 2008), do not exceed a few $\mathrm{ng} \mathrm{m}^{-3}$.

Compared to values reported in earlier studies for other locations in Athens during approximately the last decade, the trace element concentrations have remained within the same order of magnitude (Karanasiou et al., 2009; Theodosi et al., 2011; Pateraki et al., 2012; Mantas et al., 2014; Paraskevopoulou et al., 2015). As expected, the values are higher than those reported for several other rural background locations around Europe and Greece (Salvador et al., 2007; Koulouri et al., 2008; Viana et al., 2008; Pey et al., 2009; Alastuey et al., 2016).

\subsection{Chemical mass closure}

From the aerosol chemical components measured here - ion mass (IM), particulate organic mass (POM), dust, EC, and sea salt (SS) - the mass closure of the $\mathrm{PM}_{2.5}$ aerosol samples can be undertaken. IM was calculated as the sum of the non sea salt (nss) constituents $\left(\mathrm{NH}_{4}^{+}, \mathrm{NO}_{3}^{-}, \mathrm{K}^{+}, \mathrm{SO}_{4}^{-2}\right.$, $\mathrm{Br}^{-}, \mathrm{HPO}_{4}^{2-}$ and $\mathrm{C}_{2} \mathrm{O}_{4}^{-2}$ ) estimated for the compounds having a sea-salt component by using $\mathrm{Na}^{+}$as a reference and the equation described by Sciare et al. (2005).

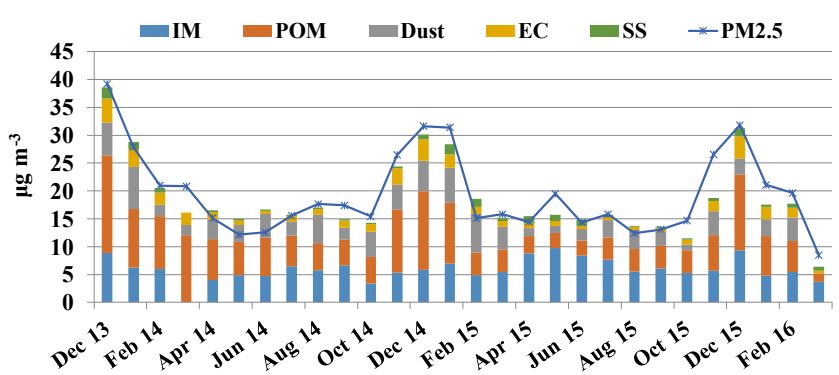

Figure 3. Annual seasonal chemical mass closure of each aerosol species for $\mathrm{PM}_{2.5}$ samples collected at Thissio for the studied period.

Dust was estimated using Al (Ho et al., 2006), assuming an upper crust concentration of $7.1 \%$ (Wedepohl, 1995). POM was estimated by multiplying the measured OC with a conversion factor (CF) of 1.8, derived from ACSM measurements in Athens (Stavroulas et al., 2018) aimed at the characterization of submicron organic aerosol sources. SSoriginating species were calculated from the sum of the following measured ions: $\mathrm{Na}^{+}, \mathrm{Cl}^{-}, \mathrm{Mg}^{2+}, \mathrm{ssK}^{+}, \mathrm{ssCa}^{2+}$, and $\mathrm{ssSO}_{4}^{2-}$ (Sciare et al., 2005; Pio et al., 2007). The results of the mass closure exercise on a mean monthly basis are shown in Fig. 3 (results on a mean seasonal basis are reported in the Supplement - Fig. S1).

The corresponding chemical mass closure can explain about $99 \%$ of the measured fine-aerosol mass, leaving out a considerably low proportion of the unaccounted mass, which is usually water (Ohta and Okita, 1990). By comparing the $\mathrm{PM}_{2.5}$ mass (determined from the filter weighting of all $12 \mathrm{~h}$ and $24 \mathrm{~h}$ samples) and the sum of individual chemical aerosol components, a significant correlation is revealed, with a slope equal to 0.98 ( $r=0.88, n=780$; not shown).

On an annual basis, POM contributes $38 \%$ to the total $\mathrm{PM}_{2.5}$ mass, while EC comprises the $8 \%$. IM also accounts for a significant part of the $\mathrm{PM}_{2.5}$ mass $(31 \%)$, with $\mathrm{SO}_{4}^{2-}$ $(16 \%)$ and $\mathrm{NH}_{4}^{+}(7 \%)$ being the dominant ions. The annual contribution of dust and SS is $18 \%$ and $3 \%$, respectively.

POM and IM present considerable seasonal variation. In winter, IM is reduced (down to $23 \%$ ), the dominant component being POM $(42 \%)$, and the rest is shared by dust (18\%), EC $(10 \%)$, and SS $(4 \%)$. In summer, IM is the main component (42\%), followed by POM (36\%), dust (24\%), EC $(5 \%)$, and SS (4\%).

\subsection{Temporal variability of winter mass and aerosol chemical composition: the role of residential heating}

\subsubsection{PM $_{2.5}$ mass}

The significant increase in fine-aerosol mass in Athens during winter compared to summer points towards an important additional PM source (Fig. 4a, b). During the wintertime, res- 

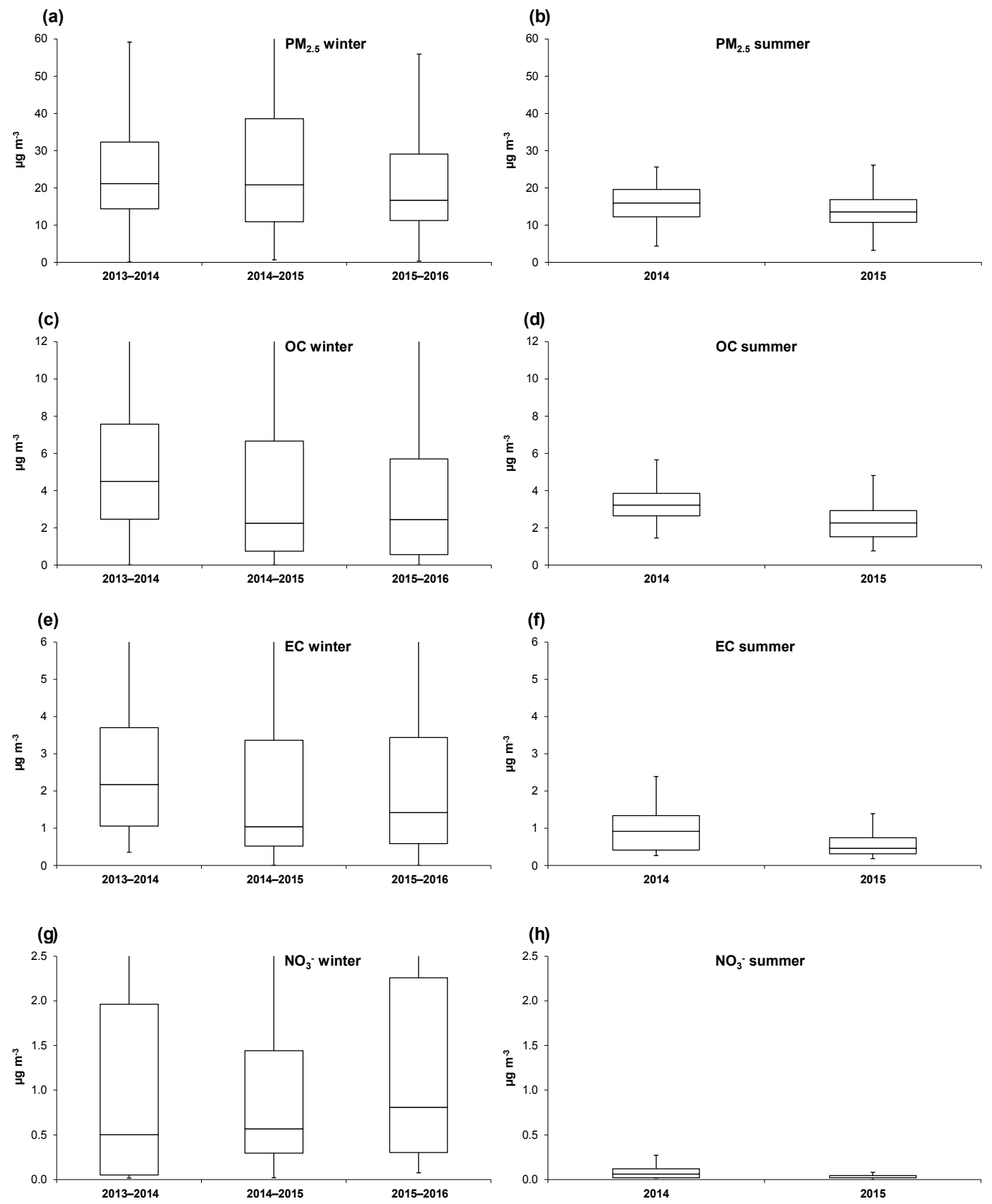

Figure 4. Winter and summer interquartile range $\left(\mu \mathrm{g} \mathrm{m}^{-3}\right)$ for $\mathrm{PM}_{2.5}$ mass, $\mathrm{OC}, \mathrm{EC}$, and $\mathrm{NO}_{3}^{-}$concentrations in the urban site of Thissio for the studied period from December 2013 to March 2016. The ends of the whisker are set at 1.5 · IQR above the third quartile (Q3) and $1.5 \cdot \mathrm{IQR}$ below the first quartile $(\mathrm{Q} 1)$.

idential heating using fossil fuel, wood, and coal are important sources of directly emitted $\mathrm{PM}_{2.5}$ (EEA, 2013, 2014). The winter stable atmospheric conditions in conjunction with the seasonal decrease of the boundary-layer height (low wind speeds, temperature inversions, and low-intensity solar radiation) could further limit the dispersion of pollutants. High levels of PM mass during winter due to wood burning have also been observed in prior studies in the two largest urban metropolitan cities in Greece, Athens and Thessaloniki (e.g., Saffari et al., 2013; Florou et al., 2017; Gratsea et al., 2017).

It is noteworthy that during winter, $\mathrm{PM}_{2.5}$ concentrations during the nighttime (mean $-32.9 \mu \mathrm{g} \mathrm{m}^{-3}$; median $\left.30.5 \mu \mathrm{g} \mathrm{m}^{-3}\right)$ are almost twice as high $(80 \%$ increase; Table 2) as during the daytime (mean $19.1 \mu \mathrm{g} \mathrm{m}^{-3}$; median $19.2 \mu \mathrm{g} \mathrm{m}^{-3}$ ), which constitutes additional evidence for the role of domestic heating. Using the approach introduced by 


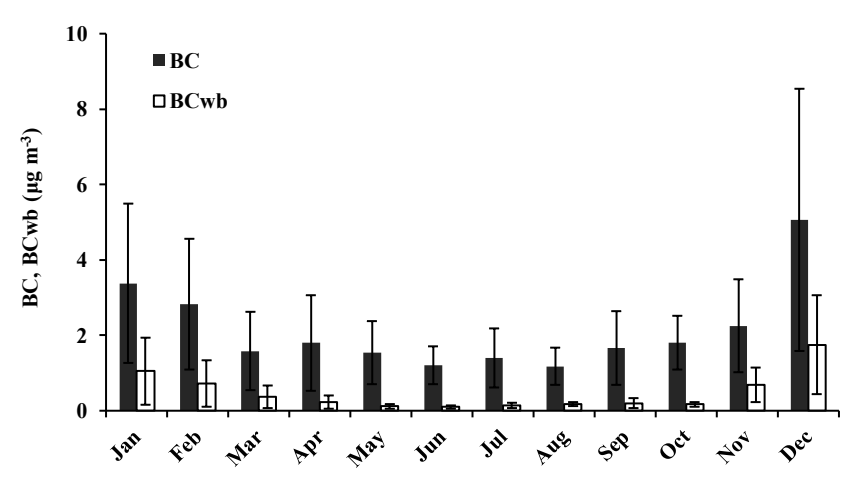

Figure 5. Seasonal variation of $\mathrm{BC}$ and $\mathrm{BC}_{\mathrm{wb}}$ at Thissio during May 2015-May 2016. The November point corresponds to black carbon measurements during the fall of 2016. Posterior data are used in order to depict a non-interrupted annual pattern.

Fourtziou et al. (2017), i.e., by selecting periods with wind speeds lower than $3 \mathrm{~m} \mathrm{~s}^{-1}$ and an absence of precipitation, 289 days with smog conditions (hereafter named SP; smog period) associated with increased levels of air pollutants (NO, CO, BC) have been identified during the three examined winters. By further studying the $\mathrm{PM}_{2.5}$ concentrations during these smog events, a $96 \%$ increase during the nighttime compared to the daytime was observed (Table 2, statistically significant at $99.9 \%$ level; $p<0.001$ ).

\subsubsection{Carbonaceous components}

Primary OC and EC from residential heating can explain the net seasonal trend with higher values during winter, as presented in Fig. 4c-f. Indeed their levels during the wintertime are higher by $55 \%$ for $\mathrm{OC}$ and $74 \%$ for EC, emphasizing the intensity and the sporadic nature of the residential heating source.

This is further evidenced by the seasonal variation of black carbon (BC) and its wood burning fraction $\left(\mathrm{BC}_{\mathrm{wb}}\right)$, obtained with the use of an aethalometer (AE33) during the period 2015-2016 (Fig. 5). BC measurements on total particulate matter (no cut-off inlet) were conducted by means of the new generation seven-wavelength Magee Scientific AE33 aethalometer, at one-minute resolution. The wood burning and fossil fuel fractions $\left(\mathrm{BC}_{\mathrm{wb}}\right.$ and $\mathrm{BC}_{\mathrm{ff}}$, respectively) were derived by the online application of the two-component model in combination with the dual-spot compensation technology provided by the instrument (Drinovec et al., 2015). Further details on the daily evolution of $\mathrm{BC}_{\mathrm{wb}}$ and $\mathrm{BC}_{\mathrm{ff}}$ fractions at the present site can be found at Gratsea et al. (2017) and Fourtziou et al. (2017).

To highlight the impact of heating on carbonaceous levels, Figure $6 \mathrm{~b}$ and $\mathrm{c}$ present their day and nighttime variability in winter. The average OC and EC concentrations increased 3 and 2 times during the night compared to the day, respectively (Table 2). A similar tendency is observed during smog events (SP, Table 2). More specifically, the average OC and EC concentrations during the night for all three winter campaigns are equal to 9.4 and $3.8 \mu \mathrm{g} \mathrm{m}^{-3}$ (12.6 and $5.1 \mu \mathrm{g} \mathrm{m}^{-3}$ for SP), respectively, with corresponding mean daytime values of 2.7 and $1.6 \mu \mathrm{g} \mathrm{m}^{-3}$ (3.4 and $2.0 \mu \mathrm{g} \mathrm{m}^{-3}$ for SP). Consequently, the contribution of POM to the total mass of $\mathrm{PM}_{2.5}$ in winter is higher during the night ( $52 \pm 4 \%$, median $50 \%$ ) than during the day $(27 \pm 10 \%$, median $23 \%$; Fig. 6b, c). Similarly, for EC in winter, a smaller yet evident average increase was also observed during the night $(12 \pm 1 \%$, median $12 \%)$ compared to the day $(8 \pm 3 \%$, median $9 \%)$.

The significant correlation between OC and EC in Athens during winter (slope $=2.36 ; r=0.94 ; n=472$ ) was more enhanced during the nighttime (slope $=2.49 ; r=0.96 ; n=$ 226) compared to the daytime $(1.62 ; r=0.85 ; n=221)$, which indicates that they originate from the same sources. Notably, the higher OC to EC ratio during summer (3.21; $r=-0.59 ; n=114)$ as well as their negative correlation could be explained by the enhanced photochemical organic aerosol formation in the atmosphere from low-volatility compounds produced by the oxidation of the gas-phase anthropogenic and biogenic precursors (Paraskevopoulou et al., 2014).

\subsubsection{Ionic composition}

$\mathrm{SO}_{4}^{2-}$ concentration in the $\mathrm{PM}_{2.5}$ fraction of aerosols did not present a pronounced seasonality, with a slightly increasing trend from spring to summer (Fig. 2b). During the dry season (spring and summer), the absence of precipitation and the increased photochemistry lead to secondary aerosol formation and increased lifetime in the area (Mihalopoulos et al., 1997), resulting in the appearance of higher concentrations. In winter, $\mathrm{SO}_{4}^{2-}$ accounts for $8 \%$ of the $\mathrm{PM}_{2.5}$ mass, while it accounts for $26 \%$ in summer. During winter, $\mathrm{SO}_{4}^{2-}$ did not show any significant day-to-night variability (about $11 \%$ increase during SP; Table 2), indicating that heating is not the major source of $\mathrm{SO}_{4}^{2-}$. In addition, the summer maxima suggest that the majority of $\mathrm{SO}_{4}^{2-}$ originates from longrange transport and thus can be considered an indicator of regional sources (Mihalopoulos et al., 1997; Theodosi et al., 2011).

The concentration of $\mathrm{NH}_{4}^{+}$presents a less pronounced seasonal trend, with a similar monthly distribution pattern as that of $\mathrm{SO}_{4}^{2-}$, in agreement to previous observations in Athens (Mantas et al., 2014; Paraskevopoulou et al., 2015). As in the case of $\mathrm{SO}_{4}^{2-}, \mathrm{NH}_{4}^{+}$did not present a day-tonight increase (less than $10 \%$ during SP; Table 2). $\mathrm{NH}_{4}^{+}$ vs. $\mathrm{SO}_{4}^{2-}$ and consequently $\mathrm{nssSO}_{4}^{2-}$ were significantly correlated $(r=0.64)$ for the entire sampling period (December 2013-March 2016), with a slope on an equivalent basis $\left(\mathrm{NH}_{4}^{+} / \mathrm{nss} \mathrm{SO}_{4}^{2-}\right)$ smaller than unity (0.62), indicating the partial neutralization of $\mathrm{nssSO}_{4}^{2-}$ by $\mathrm{NH}_{4}^{+}$. This suggests that a mixture of $\mathrm{NH}_{4} \mathrm{HSO}_{4}$ and $\left(\mathrm{NH}_{4}\right)_{2} \mathrm{SO}_{4}$ is formed in 
Table 2. The $\%$ increase in the diurnal distribution of all studied elements and species during the nighttime compared to the daytime in winter, shown for all winter samples $(n=447)$ and smog pollution events (SP, $n=289)$.

\begin{tabular}{|c|c|c|c|c|c|c|}
\hline \multirow[t]{2}{*}{$\%$} & \multicolumn{3}{|c|}{ Full winter period } & \multicolumn{3}{|c|}{ Only SP } \\
\hline & mean & SD & median & mean & SD & median \\
\hline $\mathrm{PM}_{2.5}$ & $80 \%$ **** & $120 \%$ & $55 \%$ & $96 \%$ **** & $158 \%$ & $80 \%$ \\
\hline $\mathrm{OC}$ & $254 \%{ }^{* * * *}$ & $278 \%$ & $200 \%$ & $278 \% * * * *$ & $285 \%$ & $232 \%$ \\
\hline $\mathrm{EC}$ & $134 \% \%^{* * * *}$ & $189 \%$ & $113 \%$ & $148 \%$ **** & $207 \%$ & $115 \%$ \\
\hline $\mathrm{Cl}^{-}$ & $-6 \%$ & $2 \%$ & $-6 \%$ & $-1 \%$ & $11 \%$ & $-10 \%$ \\
\hline $\mathrm{NO}_{3}^{-}$ & $53 \%$ \%*** & $32 \%$ & $90 \%$ & $53 \%$ **** & $17 \%$ & $111 \%$ \\
\hline $\mathrm{SO}_{4}^{2-}$ & $9 \%$ & $15 \%$ & $3 \%$ & $11 \%$ **** & $14 \%$ & $7 \%$ \\
\hline $\mathrm{C}_{2} \mathrm{O}_{4}^{2-}$ & $29 \% * * *$ & $18 \%$ & $33 \%$ & $28 \% *$ & $22 \%$ & $35 \%$ \\
\hline $\mathrm{Na}^{+}{ }^{4}$ & $36 \%$ & $219 \%$ & $6 \%$ & $21 \%$ & $46 \%$ & $13 \%$ \\
\hline $\mathrm{NH}_{4}^{+}$ & $13 \%$ **** & $7 \%$ & $13 \%$ & $9 \% * * * *$ & $5 \%$ & $12 \%$ \\
\hline $\mathrm{nssK}_{\mathrm{bb}}^{+}$ & $54 \% * * * *$ & $68 \%$ & $34 \%$ & $57 \% * * *$ & $53 \%$ & $39 \%$ \\
\hline $\mathrm{Mg}^{2+}$ & $-11 \%$ & $16 \%$ & $0 \%$ & $0 \%$ & $13 \%$ & $0 \%$ \\
\hline $\mathrm{Ca}^{2+}$ & $-57 \%$ & $65 \%$ & $0 \%$ & $-70 \%$ & $90 \%$ & $0 \%$ \\
\hline $\mathrm{Al}$ & $-26 \%$ & $53 \%$ & $-19 \%$ & $-11 \%$ & $40 \%$ & $-19 \%$ \\
\hline As & $11 \%$ & $2 \%$ & $26 \%$ & $22 \%$ & $4 \%$ & $70 \%$ \\
\hline $\mathrm{Cd}$ & $16 \% *$ & $6 \%$ & $0 \%$ & $37 \% * * * *$ & $12 \%$ & $0 \%$ \\
\hline $\mathrm{Cr}$ & $-2 \%$ & $20 \%$ & $-13 \%$ & $21 \%$ & $15 \%$ & $33 \%$ \\
\hline $\mathrm{Cu}$ & $-24 \%$ & $66 \%$ & $-50 \%$ & $-23 \%$ & $70 \%$ & $-50 \%$ \\
\hline $\mathrm{Fe}$ & $9 \%$ & $10 \%$ & $13 \%$ & $31 \% *$ & $5 \%$ & $29 \%$ \\
\hline V & $1 \%$ & $3 \%$ & $0 \%$ & $5 \%$ & $4 \%$ & $17 \%$ \\
\hline $\mathrm{Zn}$ & $18 \%$ & $34 \%$ & $9 \%$ & $9 \%$ & $4 \%$ & $30 \%$ \\
\hline $\mathrm{Mn}$ & $-5 \%$ & $27 \%$ & $0 \%$ & $1 \%$ & $14 \%$ & $0 \%$ \\
\hline $\mathrm{Ni}$ & $-3 \%$ & $17 \%$ & $0 \%$ & $5 \%$ & $7 \%$ & $33 \%$ \\
\hline $\mathrm{Pb}$ & $12 \% *$ & $35 \%$ & $10 \%$ & $20 \% * * * *$ & $34 \%$ & $19 \%$ \\
\hline
\end{tabular}

**** $p<0.001$ (99.9\%). ${ }^{* * *} p<0.01(99 \%) .{ }^{* *} p<0.025(97.5 \%) .{ }^{*} p<0.05(95 \%)$.

the area. Previous studies in Athens and the eastern Mediterranean have reached the same conclusion (Siskos et al., 2001; Bardouki et al., 2003; Koulouri et al., 2008). $\mathrm{NH}_{4}^{+}$is only significantly correlated to $\mathrm{NO}_{3}^{-}$in winter $(r=0.73 ; p<0.001)$, indicative of $\mathrm{NH}_{4} \mathrm{NO}_{3}$ formation, as previously suggested for the greater Athens area (GAA) (Karageorgos and Rapsomanikis, 2007; Remoundaki et al., 2013; Paraskevopoulou et al., 2015).

$\mathrm{NO}_{3}^{-}$levels present higher concentrations in the winter (Figs. 2b, 4g). This pattern is related to the formation of the $\mathrm{NH}_{4} \mathrm{NO}_{3}$ stabilized under the low temperatures prevailing during winter (Park et al., 2005; Mariani and de Mello, 2007). $\mathrm{NO}_{3}^{-}$could originate from local pollution sources, such as vehicular traffic and combustion for heating purposes. $\mathrm{NO}_{3}^{-}$levels are considerably reduced in summer (Fig. 4h) due to the thermal instability and volatilization of the $\mathrm{NH}_{4} \mathrm{NO}_{3}$ (Harrison and Pio, 1983; Querol et al., 2004). A similar seasonal pattern for $\mathrm{NO}_{3}^{-}$has been reported previously in Athens (Sillanpää et al., 2006; Paraskevopoulou et al., 2015). During winter months, $\mathrm{NO}_{3}^{-}$levels were found to be significantly higher by $53 \%$ (also $53 \%$ if SP is considered; $p<0.001$ in both cases) during the nighttime compared to the daytime, indicating a probable contribution from heating, mainly from more effective partitioning in the parti- cle phase during the colder and humid night time conditions (Fig. 6d, Table 2). A significant correlation of $\mathrm{NO}_{3}^{-}$with $\mathrm{OC}$, $\mathrm{EC}$, and $\mathrm{PM}_{2.5}$ was also observed during winter $(r=0.58$, 0.60 , and 0.56 respectively; $p<0.001$ ), further supporting their common origin. In summer no statistical significant correlation between these compounds was found.

For the rest of the ions analyzed, their seasonal distribution depends on their main sources, which can be classified into marine, mineral, or mixed. The $\mathrm{Cl}^{-}, \mathrm{Na}^{+}$, and $\mathrm{Mg}^{2+}$ controlled by sea-spray emissions are expected to have the same seasonal variability, which is related to the prevailing wind speed and direction. However, the temporal variation of $\mathrm{Mg}^{2+}$ in Athens revealed higher levels during the warm season (spring-summer), most likely from local dust resuspension and/or regional dust transport, while $\mathrm{Cl}^{-}$and $\mathrm{Na}^{+}$ present high levels during winter, most likely due to stronger southern winds prevailing during this period. $\mathrm{Cl}^{-}$and $\mathrm{Mg}^{2+}$ did not present an increase (even recording a slight decrease) during the night compared to the day. On the other hand, $\mathrm{Na}^{+}$ increased by about $21 \%$ (Table 2), indicating a small contribution from heating and especially biomass burning, as previously reported by Fourtziou et al. (2017).

Considered an effective tracer of crustal sources in the area (Sciare et al., 2005), $\mathrm{nssCa}^{+2}$ is distinctly higher in the warm 
(a)

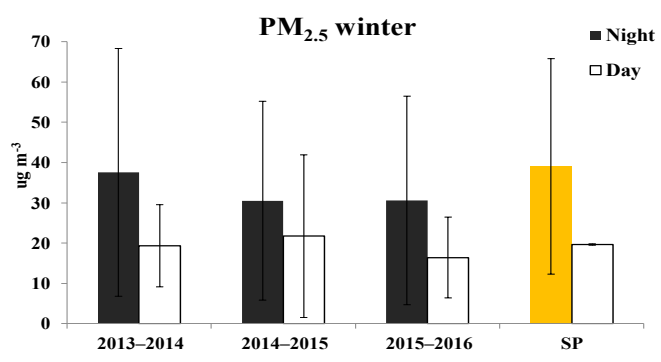

(c)

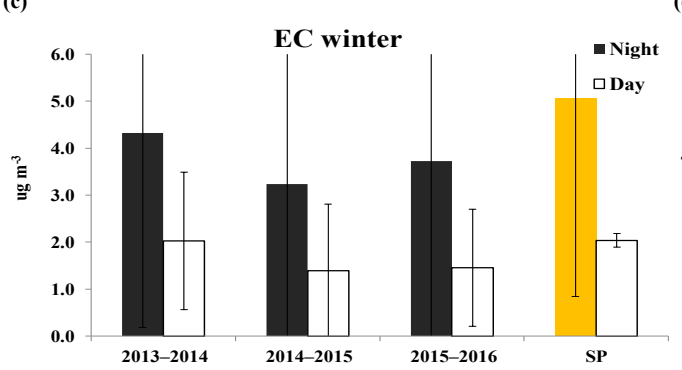

(b)

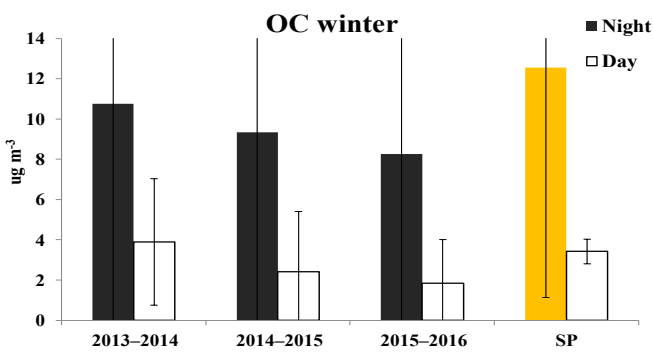

(d)

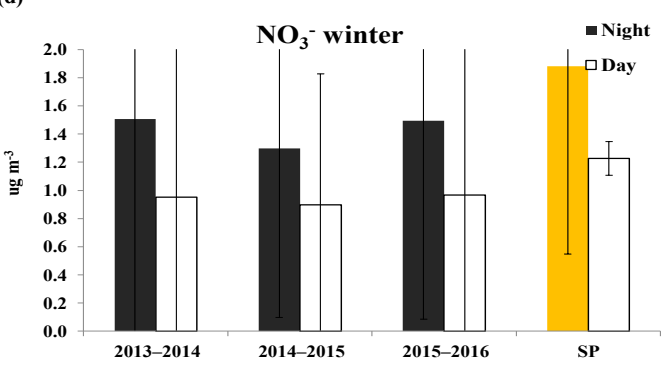

(e)

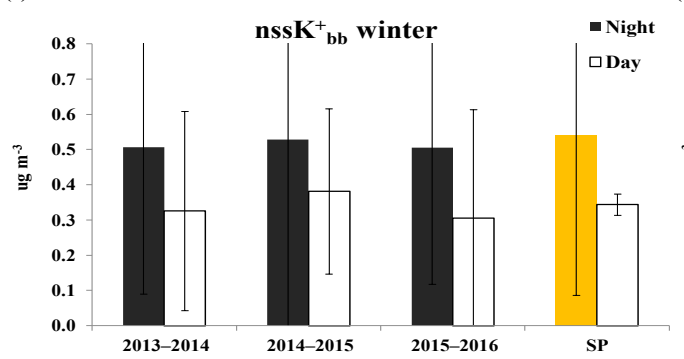

(f)

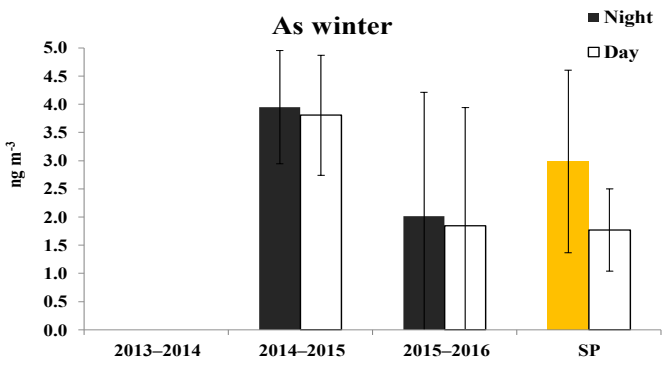

(g)

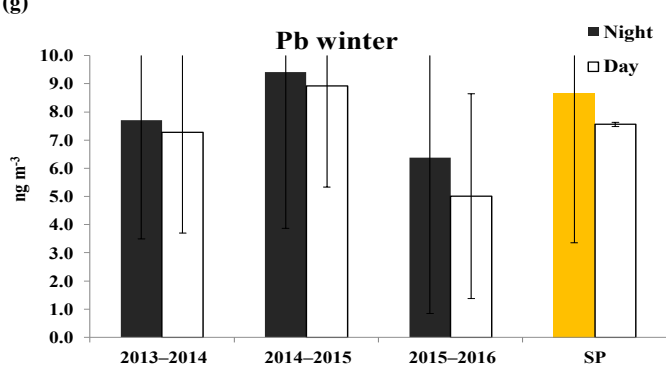

Figure 6. Winter $\mathrm{PM}_{2.5}$ mass, $\mathrm{OC}, \mathrm{EC}, \mathrm{NO}_{3}^{-}, \mathrm{nssK}_{\mathrm{bb}}^{+}$, As, and $\mathrm{Pb}$ values $\left(\mu \mathrm{g} \mathrm{m}^{-3}\right)$ divided into daytime and nighttime samples. $\mathrm{SP}$ refers to concentrations when only smog events occurred.

season due to dust transport from the Sahara and/or regional dust resuspension, the latter due to the absence of precipitation. Regarding $\mathrm{nssK}^{+}$a bimodal distribution is observed with peaks in spring and winter. The first peak is associated with Saharan dust outbreaks and the second with the result of biomass burning emissions. The latter corroborates previous reports for the online fine mode $\mathrm{K}^{+}$measured at the same site (Fourtziou et al., 2017). In order to discriminate between the influences of Saharan dust and biomass burning on $\mathrm{nssK}^{+}$levels, we have used $\mathrm{Ca}^{2+}$ as a tracer of a crustal ori- gin. During the period from March to October, with limited emissions from local biomass burning sources, $\mathrm{nssK}^{+}$and $\mathrm{Ca}^{2+}$ exhibit a significant correlation $(r=0.83)$, confirming their crustal origin. Thus, by using the $\mathrm{nssK}^{+} / \mathrm{Ca}^{2+}$ slope from their linear regression $(y=0.82 x+0.08)$, the $\mathrm{nssK}^{+}$ of a crustal origin $\left(\mathrm{K}_{\text {dust }}^{+}\right.$) can be identified allowing the further estimation the $\mathrm{nssK}^{+}$of a biomass origin $\left(\mathrm{K}_{\mathrm{bb}}^{+}\right)$from the following equation:

$$
\mathrm{K}_{\mathrm{bb}}^{+}=\mathrm{nssK}^{+}-\mathrm{K}_{\mathrm{dust}}^{+}
$$


where $\mathrm{K}_{\mathrm{bb}}^{+}$levels during the winter period account for $70 \%$ of the total $\mathrm{nssK}^{+}$levels and present a well-defined day-night contrast. Mean nighttime $\mathrm{K}_{\mathrm{bb}}^{+}$concentrations of $0.5 \mu \mathrm{g} \mathrm{m}^{-3}$ are increased by $57 \%$ relative to the daytime (Fig. 6e; Table 2; $p<0.001$ ), highlighting the role of nssK $^{+}$ as a tracer of wood burning in agreement with Fourtziou et al. (2017). During all three winter campaigns $(n>400)$, the estimated $\mathrm{K}_{\mathrm{bb}}^{+}$correlates significantly with $\mathrm{OC}, \mathrm{EC}$, and $\mathrm{NO}_{3}^{-}$, especially during the nighttime $(r=0.58,0.57$, and 0.46 , respectively) compared to the daytime ( $r=0.15$ to $0.23)$.

$\mathrm{C}_{2} \mathrm{O}_{4}^{2-}$ exhibits peaks during winter, which are due to biomass burning emissions (Kawamura et al., 1996; Kawamura and Ikushima, 1993) and during summer, which are linked to enhanced photochemistry along with increased emissions of biogenic volatile organic compounds (Theodosi et al., 2011). $\mathrm{C}_{2} \mathrm{O}_{4}^{2-}$ presents strong correlations with OC and EC during summer $(r=0.42-0.63)$ due to common emission processes such as photochemical and/or heterogeneous reactions (Myriokefalitakis et al., 2011). $\mathrm{SO}_{4}^{2-}$ presents a significant correlation with $\mathrm{C}_{2} \mathrm{O}_{4}^{2-}$ independent of the season $(r>0.54 ; p<0.001)$. Such correlations have generally been observed in many different sampling locations around the world (Pakkanen et al., 2001; Yao et al., 2003) and can be attributed to heterogeneous reactions during both seasons as proposed by Myriokefalitakis et al. (2011). During winter, from the compounds impacted by heating sources and examined so far, $\mathrm{C}_{2} \mathrm{O}_{4}^{2-}$ correlates significantly only with $\mathrm{NO}_{3}^{-}(r=0.41)$. In addition, higher concentrations at night (about $30 \%$ ) compared to during the day (Table 2) have been also observed, indicating local biomass burning emissions as possible contributors of $\mathrm{C}_{2} \mathrm{O}_{4}^{2-}$. However, the significant correlations with both $\mathrm{SO}_{4}^{2-}$ and tracers of biomass burning clearly indicate that $\mathrm{C}_{2} \mathrm{O}_{4}^{2-}$ have mixed sources of both a local and regional origin, and significant precautions are required when $\mathrm{C}_{2} \mathrm{O}_{4}^{2-}$ is used as an exclusive tracer of biomass burning.

\subsubsection{Trace metals}

\section{Crust-related elements}

$\mathrm{Al}$ is typically associated with soil-dust resuspension and is thus mainly linked to natural sources. It presents higher concentrations and larger variations during the transitional (spring and autumn) periods, when the air mass trajectories originate predominantly from North Africa and are often associated with intense sporadic peaks of mineral dust (Fig. 2c). Mn and Fe, which are affected by diverse natural and anthropogenic sources, present the same seasonal variation (Fig. 2c, f), and Mn especially reveals a statistically significant correlation with $\mathrm{Al}(r=0.59)$. However, the moderate correlation of $\mathrm{Al}$ with $\mathrm{Fe}(r=0.44)$ suggests the existence of additional sources for Fe that are most likely anthropogenic.
Regarding the diurnal pattern of $\mathrm{Al}$, it is higher by about $30 \%$ during the daytime compared to the nighttime (Table 2), most likely due to traffic-related dust resuspension. A different behavior was observed for the other two "crustal" elements, with Mn presenting no difference between the daytime and nighttime (Table 2), whereas for $\mathrm{Fe}$, slightly higher levels were observed at night compared to during the day by about $10 \%$ (Table 2). The previously described diurnal variation corroborates our hypothesis for mixed sources, natural and anthropogenic for both $\mathrm{Mn}$ and Fe, most likely from combustion emissions in addition to dust (local or regional).

\section{Elements of anthropogenic origin}

The measured trace metals originating from human activities $(\mathrm{V}, \mathrm{Cr}, \mathrm{Cd}, \mathrm{Ni}, \mathrm{Cu}, \mathrm{Cd}$, and $\mathrm{Pb}$ ) relate to a variety of sources. As presented in Fig. 2d-f, the elements of an anthropogenic origin exhibit well-defined seasonal trends, with peak values during winter as a result of additional sources, especially heating but also meteorology. When their diurnal distribution was examined during the wintertime, only $\mathrm{Cd}$ and $\mathrm{Pb}$ presented a significant increase (at $95 \%$ confidence level) during the nighttime compared to the daytime, in the range of $11 \%$ to $16 \%$ (up to about $40 \%$ when SP periods are considered; $99.9 \%$ confidence level). The above tendency indicates emissions from heating and especially wood burning, in agreement with Maenhaut et al. (2016). The other elements either present an insignificant increase in their levels during the night (in the case of $\mathrm{V}$ and $\mathrm{Ni}$ ) or even a decrease compared to the day (in the case of traffic-related $\mathrm{Cu}$ ).

Significant correlations of $\mathrm{As}$ with $\mathrm{Pb}$ and $\mathrm{Cd}(r=0.39$ and 0.66 , respectively) were observed during the whole period. When considering the three intensive winter campaigns, higher correlations were obtained between As and $\mathrm{Cd}(r=$ $0.74)$ and moderate for $\mathrm{Pb}(r=0.38)$, suggesting that heating using coal and wood could be a source of the aforementioned heavy metals (Nava et al., 2015; Maenhaut et al., 2016). In fact, As has been associated with wood combustion, where tinder treated with copper chrome arsenate (CCA) is being used for residential heating purposes (Fine et al., 2002; Khalil and Rasmussen, 2003; Alastuey et al., 2016). Strong correlations of $\mathrm{Pb}$ with $\mathrm{PM}_{2.5}, \mathrm{OC}, \mathrm{EC}, \mathrm{nssK}^{+}$, and $\mathrm{NO}_{3}^{-}$ during winter further reinforce the link with wood combustion sources at our site. Indeed, wintertime $\mathrm{Pb}$ concentrations present a significant correlation with $\mathrm{PM}_{2.5}$ mass during the nighttime $(r=0.84)$ compared to the daytime $(r=0.14)$. On the contrary, during summer, $\mathrm{Pb}$ significantly correlates with $\mathrm{Cd}(r=0.68)$, indicating the prevalence of regional sources for both elements during the non-heating season. Finally, As, $\mathrm{Pb}$, and $\mathrm{Cd}$ present no pronounced overall or season-specific associations to elements such as $\mathrm{Cu}$ and $\mathrm{Zn}$, which are considered effective brake and tire wear tracers both in general (Weckwerth, 2001; Amato et al., 2009) and in the area (Manalis et al., 2005; Grivas et al., 2018). 

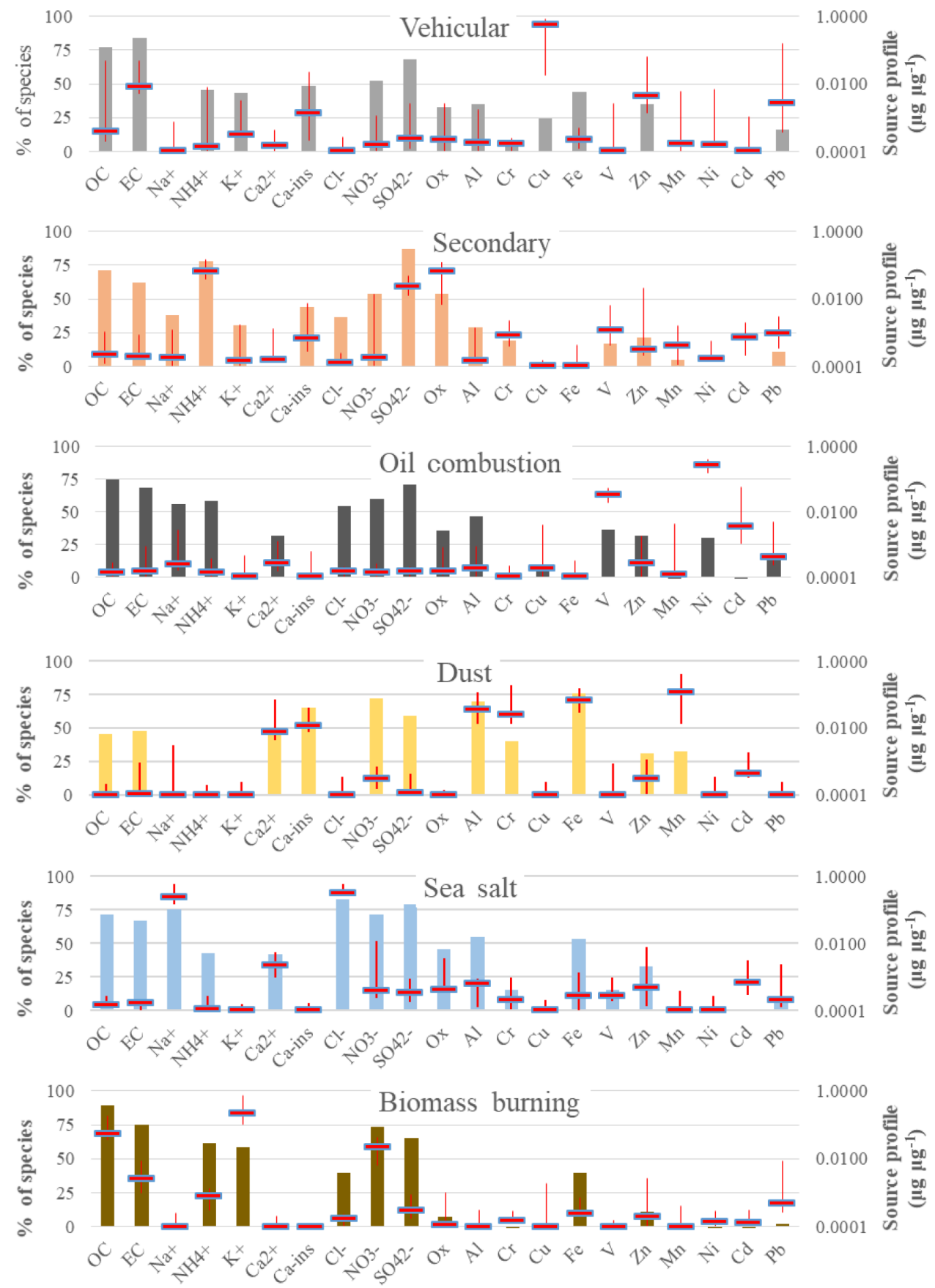

Figure 7. Average contributions to the component mass (\%, red markers) and source profiles ( $\mu \mathrm{g} \mathrm{mg}^{-1}$, colored vertical bars) of PMFresolved sources. Error bars provide the interquartile range from bootstrap resamples.

During summer relatively high correlation coefficients were calculated between $\mathrm{SO}_{4}^{2-}$ and the typical heavy oil combustion tracers $\mathrm{V}$ and $\mathrm{Ni},(r=0.69$ and 0.60$)$, respectively. This indicates common emission patterns and source types such as shipping. The $\mathrm{V} / \mathrm{Ni}$ ratio during that period was equal to 1.2, slightly lower than the range of 2 to 4 reported by Viana et al. (2008) to identify shipping emissions, pointing to additional fuel combustion sources. During winter the poorer correlation of $\mathrm{V}$ with $\mathrm{Ni}(r=0.16)$ can be explained by a decrease in shipping activities, thus $\mathrm{Ni}$ could be related to petrochemical and metallurgical activities (see below). 
Table 3. Average day and night contributions of identified sources to $\mathrm{PM}_{2.5}\left(\mu \mathrm{g} \mathrm{m}^{-3}\right)$. Respective percentages in parentheses. Statistical significance $(p)$ refers to differences for day-night pairwise comparison assessed with Wilcoxon signed-rank non-parametric tests.

\begin{tabular}{lrrr}
\hline Source & Day & Night & Significance $(p)$ \\
\hline Biomass burning & $3.3(19)$ & $11.3(39)$ & $0.00^{*}$ \\
Vehicular & $3.4(19)$ & $5.4(19)$ & 0.10 \\
Secondary & $5.4(31)$ & $4.2(14)$ & $0.00^{*}$ \\
Oil combustion & $1.4(8)$ & $1.6(6)$ & 0.55 \\
Dust & $1.7(10)$ & $1.9(7)$ & 0.48 \\
Sea salt & $2.2(12)$ & $2.1(7)$ & 0.17 \\
Unaccounted & $0.2(1)$ & $2.4(8)$ & \\
\hline
\end{tabular}

* Significant at the 0.05 level.

\subsection{Wintertime $\mathbf{P M}_{2.5}$ source apportionment}

\subsubsection{PMF modeling}

The model identified six unique factors, characterized as biomass burning, vehicular emissions, regional secondary, heavy oil combustion, dust particles and sea salt. Factor contributions to modeled concentrations of species and source profiles are presented in Fig. 7. The average contributions of factors to $\mathrm{PM}_{2.5}$ concentrations are shown separately for daytime and nighttime sampling periods in Table $3 . \mathrm{PM}_{2.5}$ concentrations were adequately reproduced by the model with a high correlation coefficient and slope in modeled vs. observed value regression $(r=0.92$, slope $=0.94$; intercept is not significantly different from 0 ). Results of the BS-DISP error estimation process, with over $95 \%$ accurate bootstrap mapping, the small change of the $Q$ value, and minimal factor swaps indicated the stability of the solution. Details are provided in Supplement Table S1 according to the recommendations of Brown et al. (2015). Additional PMF results for the full 2-year period of March 2014-February 2016 are shown in Figs. S2 and S3.

\subsubsection{Source profiles and contributions}

\section{Biomass burning (BB)}

The factor is identified by the strong presence of $\mathrm{K}^{+}$and elevated OC/EC ratios (3.7 on average), suggestive of nonfossil fuel primary emissions. Small amounts of $\mathrm{Cl}^{-}, \mathrm{C}_{2} \mathrm{O}_{4}^{2-}$, $\mathrm{Fe}$ and $\mathrm{Pb}$ were also included (Maenhaut et al., 2016), once again indicating wood-burning associations, which have been suggested in Sect. 3.4.4, "Elements of anthropogenic origin" (Table 2). Ratios of $\mathrm{SO}_{4}^{2-}$ to $\mathrm{K}^{+}$below unity likely indicate relatively fresh biomass burning emissions (Viana et al., 2013). Source contributions correlated highly to aethalometer-determined $\mathrm{BC}_{\mathrm{wb}}(r=0.88)$. Strong correlations $(r=0.93)$ were also observed for the winter of 20152016 , with the mass fragment of $m / z 60$ that was quan- tified by an aerosol chemical speciation monitor (ACSM) concurrently operating at the same site (Stavroulas et al., 2018). The $m / z \quad 60$ fragment is considered a good tracer for biomass burning emissions (Alfarra et al., 2007), and its levels are closely associated with levoglucosan concentrations. Approximately $35 \%$ of EC concentrations are attributed to biomass burning, close to the average wintertime $\mathrm{BC}_{\mathrm{wb}}$ fraction, which is equal to $32 \%$ for the winter period 2015-2016 (Fig. 5) and 44\% during 2013-2014 (Fourtziou et al., 2017). Comparably elevated $\mathrm{BC}_{\mathrm{wb}}$ contributions to BC (29\%-32\%) have been reported for the winter of 2014-2015 at two background locations in the Greater Athens Area (Kalogridis et al., 2018). Similarly, for OC, the PMF-calculated BB contribution of $2.6 \mu \mathrm{g} \mathrm{m}^{-3}$ to fine OC is comparable to the $2.3 \mu \mathrm{g} \mathrm{m}^{-3}$ of biomass burning organic aerosol estimated to be present in submicron non-refractory OM in Thissio during the winter of 2013 (Florou et al., 2017).

The average contribution of the $\mathrm{BB}$ factor in $\mathrm{PM}_{2.5}$ during the nighttime is estimated as 3.4 times the daytime value, double the respective increase (1.7 times) in fineaerosol mass (Table 2). Overall, biomass burning was found to be the source with the largest input to wintertime $\mathrm{PM}_{2.5}$ concentrations in the urban background setting of central Athens. Biomass burning has been recognized as an important contributor to fine particle levels in post-recession Athens, with mean annual contributions varying between $7 \%-10 \%$ (Paraskevopoulou et al., 2015; Amato et al., 2016). In the present case, for the confined wintertime period, the average share of the BB factor was found to be much higher $(31 \%)$. Such large wintertime contributions are increasingly being reported for urban background locations in southern Europe (Nava et al., 2016; Squizzato et al., 2016; Diapouli et al., 2017; Cesari et al., 2018). Florou et al. (2017) have attributed $25 \%$ of wintertime (2013) non-refractory submicron aerosol to biomass burning organics at the same site, a result compatible with the presently estimated contribution.

Comparing the BB factor contributions between the two winter periods (2014-2015 and 2015-2016), a decrease of $33 \%$ in the mean concentrations attributed to BB was found. A comparable difference $(41 \%)$ was observed for mean $\mathrm{BC}_{\mathrm{wb}}$ concentrations determined by aethalometer measurements. Both were found to be statistically significant at the 0.01 level. The variation in meteorological parameters factored in the observed difference. Cold conditions were relatively harsh during the first winter, with the mean minimum daily temperature being lower by $1.5^{\circ} \mathrm{C}$ and more frequent northern synoptic-scale winds transporting cold air masses. Moreover, according to data from the Hellenic Statistical Authority, the amount of heating oil sold in Greece in 2015 increased by $51 \%$ compared to the previous year (reaching 0.4 million metric tons as opposed to 0.9 million before the recession), mostly because of lower prices (up to $20 \%$ between 2014 and 2015, due to declining crude oil values). Thus, the use of biomass burning for space heating during the second winter was reasonably expected to have decreased. 
Although estimated contributions during the wintertime are severe, they are largely curbed on a year-round basis. Results from the full-period PMF analysis (Fig. S3) indicate a year-round average (March 2014-February 2016) contribution of the BB factor amounting to $2.3 \mu \mathrm{g} \mathrm{m}^{-3}$, with a share of $13 \%$ to the $\mathrm{PM}_{2.5}$ mass. The result is justified, taking into account that biomass burning for residential heating also extends as a source into November and March, which have not been included in the winter-only analysis, given also the documented summertime long-range transport of agricultural burning emissions to southern Greece (Bougiatioti et al., 2014). The estimated mean annual fractional contribution of $13 \%$ is elevated compared to those reported by Grivas et al. (2018) at an urban background location in central Athens (8\%) during 2011-2012 and by Amato et al. (2016) at a suburban background site (10\%) during 2013.

Due to the fact that only water-soluble $\mathrm{K}^{+}$was included as a tracer for biomass burning in the PMF analysis, it is possible that some uncertainty is associated with estimated contributions (Pachon et al., 2013). In order to provide an indication of such an uncertainty and in the absence of levoglucosan measurements, we have repeated the PMF analysis for the winter of 2015-2016, adding data on the $m / z 60$ and $m / z, 73$ mass fragments from collocated ACSM measurements. These have been validated as important BB tracers at the present site, displaying strong correlations with levoglucosan, as detailed in Fourtziou et al. (2017). A combination of data from chemical analysis and aerosol mass spectrometry in the same receptor model has been occasionally reported in the literature (Li et al., 2004; Dall'Osto et al., 2014).

A similar six-factor solution was again obtained, and based on the comparison of resulting BB explained variances and contributions with those of the original dataset (Figs. S4 and S5), differences were found to be small. The source profiles closely agree, and a mean absolute difference of $2.2 \%(0 \%-10.5 \%)$ was calculated for explained variances of species. The average difference in the factor contribution to $\mathrm{PM}_{2.5}$ for the winter of $2015-2016$ was $+0.60 \mu \mathrm{g} \mathrm{m}^{-3}$ (higher in the original solution). The latter is analyzed as $+0.61 \mu \mathrm{g} \mathrm{m}^{-3}$ in daytime and $+0.57 \mu \mathrm{g} \mathrm{m}^{-3}$ in nighttime average contributions. The mean difference of the fractional contribution to $\mathrm{PM}_{2.5}$ is $3.3 \%$.

$\mathrm{NO}_{3}^{-}$was predominantly classified as the biomass burning factor. $\mathrm{NO}_{3}^{-}$in central Athens is formed as a product of fast chemical processes involving fresh $\mathrm{NO}_{x}$ emissions at a local level (Theodosi et al., 2011). In cold-weather conditions, nitrate condensation of semi-volatile ammonium nitrate in the particle phase is enhanced. Especially during the night, when temperatures drop significantly and fresh woodburning $\mathrm{NO}_{x}$ is abundant, nitrate concentrations rise significantly (53\%; Sect. 3.4.3), establishing a pattern of temporal covariance with biomass burning indicators (Xie et al., 2008; Amato et al., 2016). Moreover, associations between biomass burning aerosols and nitrate that are observed in southern Greece (Bougiatioti et al., 2014) have been attributed to re- duced acidity, which facilitates $\mathrm{NO}_{3}^{-}$partitioning in the particle phase (Guo et al., 2016). Higher nighttime $\mathrm{pH}$ values are anticipated both due to the ionic content of wood-burning emissions and because of increased water content during the nocturnal hours (Bougiatioti et al., 2016), especially in humid conditions favorable for the occurrence of wintertime smog events.

While a separate secondary nitrate factor has been occasionally identified in PMF studies in Athens (Amato et al., 2016), in this winter fine particle dataset, it was not possible to obtain a stable solution with more than six factors. The absence of a nitrate factor in PMF results for PM in Athens has also been reported by Paraskevopoulou et al. (2015) and Diapouli et al. (2017). The latter, at two urban and suburban background sites in Athens, presented a nitrate mass fraction in the BB factor similar to the one presently reported (around $0.1 \mu \mathrm{g} \mathrm{g}^{-1}$ ), with the factor being the main contributor to fine nitrate. Since the possibility that the secondary nitrate included in the BB factor might be inflating its contribution cannot be completely ruled out, the total nitrate attributed to the factor $\left(\right.$ as $\left.\mathrm{NH}_{4} \mathrm{NO}_{3}\right)$ has been considered an upper bound of overestimation. In this case, the overestimation during the daytime and nighttime would be 0.44 and $1.46 \mu \mathrm{g} \mathrm{m}^{-3}$, respectively. The contributions of the factor to the $\mathrm{PM}_{2.5}$ would still be $17 \%$ and $35 \%$ during the 2-day periods ( $2 \%$ and $4 \%$ less than calculated). For comparison, Amato et al. (2016) have reported an annual secondary nitrate contribution of $0.7 \mu \mathrm{g} \mathrm{m}^{-3}$ for $\mathrm{PM}_{2.5}$ in suburban Athens.

\section{Fossil fuel sources (VEH and OIL)}

The vehicular emissions factor (VEH) is characterized by an abundance in $\mathrm{EC}, \mathrm{OC}$, and $\mathrm{Cu}$ and to a lesser extent, $\mathrm{Zn}$, $\mathrm{Pb}$, and insoluble $\mathrm{Ca}$, which is most likely related to trafficinduced resuspension of dust (Kassomenos et al., 2012) in the calcite-rich Attica region (Sillanpää et al., 2005). Factor contributions correlate well with the fossil fuel fraction of $\mathrm{BC}\left(\mathrm{BC}_{\mathrm{ff}}, r=0.87\right)$. The factor also correlates much better than the biomass burning factor with $\mathrm{NO}_{x}(r=0.94)$ and $\mathrm{CO}(r=0.91)$ concentrations, measured at a nearby roadside traffic site $(0.9 \mathrm{~km}$ to the NE) and used as indicators of local traffic variability (respective correlations with $\mathrm{BB}$ factor; $r-\mathrm{NO}_{x}=0.60, r-\mathrm{CO}=0.61$ ). Moreover, the factor is significantly anti-correlated with the $\mathrm{CO} / \mathrm{NO}_{x}$ concentration ratio $(r=-0.60)$, which has been used to discern between traffic and $\mathrm{BB}$ emissions, since the latter contain more $\mathrm{CO}$ in comparison with combustion in engines where, due to higher temperatures, a larger amount of $\mathrm{NO}_{x}$ is produced (Sandradewi et al., 2008). The EC/OC ratio in the factor equals 0.62, suggestive of vehicular exhaust emissions (Pio et al., 2011). The overall contribution of $19 \%$ to $\mathrm{PM}_{2.5}$ is reasonable for urban background locations in Europe (Belis et al., 2013) and are comparable to previous results in Athens (Paraskevopoulou et al., 2015). While an interference of fuel emissions from domestic heating cannot be completely ex- 
cluded in the factor, it is believed that it would not be significant, given the low share of heating oil combustion to total PM emissions from domestic heating in Greece (Fameli and Assimakopoulos, 2016). Average nighttime contributions are slightly higher (by a factor of 1.5); however, the difference was not statistically significant at the 0.05 level.

The oil combustion factor (OIL) is dominated by the presence of $\mathrm{V}$ and $\mathrm{Ni}$ at ratios indicative of residual oil combustion (V/Ni: 1.8). Sulfate is present at the source profile, with a contribution of $0.07 \mu \mathrm{g} \mathrm{gg}^{-1}$ and an explained variance of $4.4 \%$, values that are relatively small but within the range of those reported for oil combustion factors in other cities in the Mediterranean (Amato et al., 2016; Koçak et al., 2011; Reche et al., 2012). The observed V / Ni ratio appears to fall short from the typical values reported for shipping emissions (Pandolfi et al., 2011). In Athens, a major part of shipping emissions that affect the inner parts of the basin derive from passenger and cruise ship activity, which diminishes during the winter months. Karageorgos and Rapsomanikis (2010) have reported wintertime $\mathrm{V} / \mathrm{Ni}$ ratios of 1.5-1.9 for sites in central Athens and for fine particles deriving from mixed harbor and industrial emissions in the S-SW part of Athens. As it can be seen in Fig. S6a, b, moderately high contributions are associated with westerly advection from the industrialized Thriassion plain, while exceedances of the 75 th percentile are more probable with winds from the harbor zone to the south. No pronounced day-night contrasts were observed, indicating that oil combustion for residential heating should not influence the source profile. The average contribution of the factor in $\mathrm{PM}_{2.5}\left(7 \%, 1.5 \mu \mathrm{g} \mathrm{m}^{-3}\right)$ is within the range reported for Mediterranean areas affected by harbor emissions (Pérez et al., 2016).

\section{Secondary sources (SEC)}

The factor is characterized mainly by the presence of sulfate. The observed $\mathrm{SO}_{4}^{2-} / \mathrm{NH}_{4}^{+}$ratio in the source profile (2.2) is close to stoichiometric, modified by the presence of $\mathrm{NH}_{4} \mathrm{NO}_{3} \cdot \mathrm{C}_{2} \mathrm{O}_{4}^{2-}$ is predominantly associated with this factor, its close correlation to $\mathrm{SO}_{4}^{2-}$ having been attributed to common in-cloud processing mechanisms (Yu et al., 2005), in agreement with the results in Sect. 3.4.3. The $\mathrm{OC} / \mathrm{EC}$ ratio exceeds the value of two (2.2). In comparison to year-round observations, reduced $\mathrm{OC} / \mathrm{EC}$ ratios (Grivas et al., 2012) and regional contributions (Paraskevopoulou et al., 2015) have been documented in the area during winter months due to limited formation of secondary organics from photo-oxidation processes. Higher contributions were observed during the daytime, most likely due to increased photochemical activity. Grivas et al. (2018) estimated $5.5 \mu \mathrm{g} \mathrm{m}^{-3}$ of secondary regional contribution for the cold period of 2011-2012 (extending from mid-October to mid-April) at an urban background location in Central Athens, consistent with values presently reported. When the analysis was conducted for the full period, this sulfate- and OC-rich factor arises as the key contributor to $\mathrm{PM}_{2.5}$ (38\%), owing to increased regional photochemical production (Hasheminassab et al., 2014). Its share is comparable with results reported for fine particles at background locations in Athens, which indicate a contribution range of $27 \%-54 \%$ (Paraskevopoulou et al., 2015; Mantas et al., 2014).

\section{Natural sources (DUST and SS)}

The factor identified as dust is characterized by the presence of $\mathrm{Al}, \mathrm{Fe}, \mathrm{Ca}$ (soluble and insoluble), and $\mathrm{Mn}$. The observed ratio of $\mathrm{Fe} / \mathrm{Al}$ (1.9) is higher than the values reported for local topsoil (Argyraki and Kelepertzis, 2014) or for Saharan dust (Formenti et al., 2003). It appears that road dust - rich in trace elements deriving from mechanical wear - is incorporated in the dust factor as indicated above in Sect. 3.4.4, "Crust-related elements". A further indication of the participation of road dust is the abundance of $\mathrm{Cr}$ in the factor, which is largely enriched (enrichment factor EF $>100$, using $\mathrm{Al}$ as the reference element) with respect to the upper crust composition (Wedepohl, 1995). Dust contributions do not present significant day-night variability, and they account for $8 \%$ of the $\mathrm{PM}_{2.5}$ concentrations overall, which is in line with contributions to $\mathrm{PM}_{2.5}$ reported for the urban background of central Athens during 2011-2012 (Grivas et al., 2018).

High contributions to $\mathrm{Cl}^{-}$and $\mathrm{Na}^{+}$are characteristic of the marine aerosol factor, which records higher-than-median contributions, mainly during moderate flows from the sea, $5 \mathrm{~km}$ to the $\mathrm{S}$ of the site (Fig. S6c). $\mathrm{Ca}^{2+}$ ions participate at a fraction of $\mathrm{Cl}^{-}$representative of the composition of seawater, while insoluble $\mathrm{Ca}$ does not participate in the factor (Tan et al., 2016). $\mathrm{Cl}^{-}$depletion is limited during the winter months, allowing for a more realistic quantification of the input of marine aerosols to the fine-particle fraction. A relatively high contribution of the factor to particle mass (9\% in winter, $7 \%$ on a year-round basis) is noted in comparison to past studies in Athens (Paraskevopoulou et al., 2015; Amato et al., 2016), probably related to the closer vicinity of the site to the sea.

\section{Conclusions}

This study reports detailed measurements of $\mathrm{PM}_{2.5}$ chemical composition at central Athens, from December 2013 to March 2016, including three intensive winter campaigns. Approximately 850 daily $\mathrm{PM}_{2.5}$ samples were collected and analyzed for the main ions, trace metals, OC, and EC, quantifying a range of useful tracers for monitoring the contribution of the different sources to the aerosol load in Athens.

From the results, it appears that in spite of reductions in anthropogenic emissions during the past years, mean annual $\mathrm{PM}_{2.5}$ levels persist in the vicinity of $20 \mu \mathrm{g} \mathrm{m}^{-3}$, a value of relevance for increased population exposure in urban background areas as evidenced by its selection in the EU Average Exposure Indicator of the 2008/50/EC directive. 
Levels of both POM and EC considerably increased during winter (POM $11.6 \mu \mathrm{g} \mathrm{m}^{-3}$; EC, $2.8 \mu \mathrm{g} \mathrm{m}^{-3}$ ) compared to summer (POM $5.2 \mu \mathrm{g} \mathrm{m}^{-3}$; EC $0.7 \mu \mathrm{g} \mathrm{m}^{-3}$ ), underlining the major role of heating-related emissions during winter in Athens. It is noteworthy that winter EC levels exceed mean winter EC concentrations measured in $\mathrm{PM}_{10}$ at a roadside location in central Athens, 10 years prior to this study (Grivas et al., 2012), indicating the recent intensification of wintertime emissions of carbonaceous compounds.

Ionic concentrations exhibit a summer maximum, with $\mathrm{SO}_{4}^{2-}$ and $\mathrm{NH}_{4}^{+}$concentrations up to 3.8 and $1.7 \mu \mathrm{g} \mathrm{m}^{-3}$, respectively. This is related to the significant contribution of photochemistry during that period combined with less precipitation and higher regional transport, as both compounds are related to regional rather than local sources. Overall, the long-term sulfate measurements indicate that levels in the area have progressively declined during the last two decades, reflecting the reductions in regional emissions of sulfur oxides from energy production in Greece.

The importance of residential heating was highlighted by examining the diurnal variation of measured species during the wintertime. During the heating period, from November to February, $\mathrm{PM}_{2.5}, \mathrm{POM}, \mathrm{EC}, \mathrm{NO}_{3}^{-}$, $\mathrm{nssK}^{+}$, and $\mathrm{C}_{2} \mathrm{O}_{4}^{2-}$ significantly increased during the nighttime compared to the daytime due to the intensive use of fossil fuel and wood for heating purposes. Heavy metals such as $\mathrm{As}, \mathrm{Cd}$, and $\mathrm{Pb}$ were also found to be associated to heating activities in winter. However, the present results from long-term measurements indicate that violations of the EU target values for $\mathrm{As}, \mathrm{Cd}$, and $\mathrm{Ni}$ as defined in the 2004/107/EC directive are unlikely at urban background locations in the area.

In order to further quantify the importance of residential heating during winter in the city center of Athens, PMF source apportionment was performed with specific emphasis on day-night patterns. Biomass burning was found to be the source with the largest input to wintertime $\mathrm{PM}_{2.5}$ concentrations $(32 \%)$ in the urban background site of central Athens, with a higher nighttime contribution (39\%) to the $\mathrm{PM}_{2.5}$ compared to the daytime (19\%). The vehicular emissions and oil combustion factors contributed almost equally at night and during the day (19\% and $7 \%$ for the two factors, respectively). The factors representing natural emissions (crustal and marine) presented slightly higher contributions during the daytime (9\% dust and $11 \%$ SS) compared to the nighttime (6\% dust and $7 \%$ SS). Regional secondary sources were found to be the source with the largest input to winter daytime $\mathrm{PM}_{2.5}$ concentrations equal to $30 \%$, higher by a factor of almost 2 compared to the nighttime contributions.

Based on these source apportionment results, one can infer that biomass burning can account for a large part of the observed increase in $\mathrm{PM}_{2.5}$ levels in the winter at night. Moreover, the smog events are likely to inflate the number of exceedances of the $24 \mathrm{~h}$ limit value for $\mathrm{PM}_{10}$ samples at the station. It is noteworthy that the contribution of the biomass burning factor was estimated over $10 \mu \mathrm{g} \mathrm{m}^{-3}$ on $31 \%$ of the analyzed days. In spite of severe levels during the wintertime, the results of the extended two-year PMF analysis indicated a much lower mean contribution to $\mathrm{PM}_{2.5}$ on an annual basis.

An important effect of wintertime biomass burning emissions is the reversal of the long-established seasonal pattern of PM concentrations at urban background sites in Athens. Whereas prior to the recession, the monthly variation of $\mathrm{PM}_{10}$ and $\mathrm{PM}_{2.5}$ concentrations at urban and suburban background sites produced an enhancement during the summer period attributed to secondary particles (Kassomenos et al., 2014), the results from this long-term study indicated that wintertime levels in the urban background of Athens are now significantly higher during winter.

It has been demonstrated that the contribution of the BB factor triples during the evening and night hours in the wintertime. On the one hand, such an increase is notable, even though its direct impact for population exposure might be moderated by the fact that the majority of the population stays mostly indoors during this time frame. On the other hand, this specific source type has been also linked to significant indoor exposure from fireplaces and wood stoves, so its effects are adding up.

Given the apparent importance of biomass burning as a major pollution source in Athens - escalating since the winter of 2012 - chemical composition measurements should continue in order to track its year-to-year variability. Additionally, estimations of the biomass burning-related sources using other approaches such as high resolution measurements of the organic submicron fraction (i.e., the work by Stavroulas et al., 2018) should be helpful in elucidating not only the potential impacts of this environmental issue, but also the related dynamic processes in the atmospheric chemistry of urban areas.

Data availability. Data are available upon request from the authors (mail to mihalo@uoc.gr and c_theodosi@chemistry.uoc.gr).

Supplement. The supplement related to this article is available online at: https://doi.org/10.5194/acp-18-14371-2018-supplement.

Author contributions. CT contributed to sample analysis, data interpretation, and the drafting of the article. MT, PZ, EL, DP, and ML collected and analyzed samples for the variables presented in this work. GG contributed to source identification and drafted the appropriate part of the manuscript. NM and EG devised the study and performed critical revisions of the article, including the final approval of the version to be published. 
Competing interests. The authors declare that they have no conflict of interest.

Special issue statement. This article is part of the special issue "CHemistry and AeRosols Mediterranean EXperiments (ChArMEx) (ACP/AMT inter-journal SI)". It is not associated with a conference.

Acknowledgements. Christina Theodosi and Nikolaos Mihalopoulos acknowledge support by the State Scholarship Foundation ("IKY Fellowships of Excellence for Postgraduate Studies in Greece - Siemens Programme") in the framework of the Hellenic Republic-Siemens Settlement Agreement. Christina Theodosi, Eleni Liakakou, and Evangelos Gerasopoulos acknowledge support from Niarchos Foundation. This study also received financial support from the European Community through the Aerosols, Clouds, and Trace gases Research InfraStructure Network (ACTRIS) Research Infrastructure Action under the 7th Framework Programme (Grant agreement no. 262254). We would also like to thank the editor and the three anonymous reviewers for their comments that helped us to improve the initially submitted version.

Edited by: Xavier Querol

Reviewed by: three anonymous referees

\section{References}

Alastuey, A., Querol, X., Aas, W., Lucarelli, F., Pérez, N., Moreno, T., Cavalli, F., Areskoug, H., Balan, V., Catrambone, M., Ceburnis, D., Cerro, J. C., Conil, S., Gevorgyan, L., Hueglin, C., Imre, K., Jaffrezo, J.-L., Leeson, S. R., Mihalopoulos, N., Mitosinkova, M., O’Dowd, C. D., Pey, J., Putaud, J.-P., Riffault, V., Ripoll, A., Sciare, J., Sellegri, K., Spindler, G., and Yttri, K. E.: Geochemistry of $\mathrm{PM}_{10}$ over Europe during the EMEP intensive measurement periods in summer 2012 and winter 2013, Atmos. Chem. Phys., 16, 6107-6129, https://doi.org/10.5194/acp16-6107-2016, 2016.

Alfarra, M. R., Prevot, A. S. H., Szidat, S., Sandradewi, J., Weimer, S., Lanz, V. A., Schreiber, D., Mohr, M., and Baltensperger, U.: Identification of the mass spectral signature of organic aerosols from wood burning emissions, Environ. Technol. Sci., 41, 57705777, 2007.

Amato, F., Pandolfi, M., Viana, M., Querol, X., Alastuey, A., and Moreno, T.: Spatial and chemical patterns of $\mathrm{PM}_{10}$ in road dust deposited in urban environment, Atmos. Environ., 43, 16501659, 2009.

Amato, F., Alastuey, A., Karanasiou, A., Lucarelli, F., Nava, S., Calzolai, G., Severi, M., Becagli, S., Gianelle, V. L., Colombi, C., Alves, C., Custódio, D., Nunes, T., Cerqueira, M., Pio, C., Eleftheriadis, K., Diapouli, E., Reche, C., Minguillón, M. C., Manousakas, M.-I., Maggos, T., Vratolis, S., Harrison, R. M., and Querol, X.: AIRUSE-LIFE+: a harmonized PM speciation and source apportionment in five southern European cities, Atmos. Chem. Phys., 16, 3289-3309, https://doi.org/10.5194/acp16-3289-2016, 2016.
Argyraki, A. and Kelepertzis, E.: Urban soil geochemistry in Athens, Greece: The importance of local geology in controlling the distribution of potentially harmful trace elements, Sci. Total Environ., 482-483, 366-377, 2014.

Bardouki, H., Liakakou, H., Economou, C., Sciare, J., Smolik, J., Zdimal, V., Eleftheriadis, K., Lazaridis, M., Dye, C., and Mihalopoulos, N.: Chemical composition of size-resolved atmospheric aerosols in the Eastern Mediterranean during summer and winter, Atmos. Environ., 37, 195-208, 2003.

Beddows, D. C. S., Donovan, R. J., Harrison, R. M., Heal, M. R., Kinnersley, R. P., King, M. D., Nicholson, D. H., and Thompson, K. C.: Correlations in the chemical composition of rural background atmospheric aerosol in the UK determined in real time using time-of-flight mass spectrometry, J. Environ. Monitor., 6, 124-133, 2004.

Belis, C. A., Karagulian, F., Larsen, B. R., and Hopke, P. K.: Critical review and meta-analysis of ambient particulate matter source apportionment using receptor models in Europe, Atmos. Environ., 69, 94-108, 2013.

Bell, M. L., Ebisu, K., Peng, R. D., Samet, J. M., and Dominici, F.: Hospital admissions and chemical composition of fine particle air pollution, Am. J. Resp. Crit. Care, 179, 1115-1120, 2009.

Bernardoni, V., Vecchi, R., Valli, G., Piazzalunga, A., and Fermo, P.: $\mathrm{PM}_{10}$ source apportionment in Milan (Italy) using time-resolved data, Sci. Total Environ., 409, 4788-4795, 2011.

Beuck, H., Quass, U., Klemm, O., and Kuhlbusch, T. A. J.: Assessment of sea salt and mineral dust contributions to $\mathrm{PM}_{10}$ in $\mathrm{NW}$ Germany using tracer models and positive matrix factorization, Atmos. Environ., 45, 5813-5821, 2011.

Birch, M. E. and Cary, R. A.: Elemental carbon-based method for monitoring occupational exposures to particulate diesel exhaust, Aerosol. Sci. Technol., 25, 221-241, 1996.

Bougiatioti, A., Stavroulas, I., Kostenidou, E., Zarmpas, P., Theodosi, C., Kouvarakis, G., Canonaco, F., Prévôt, A. S. H., Nenes, A., Pandis, S. N., and Mihalopoulos, N.: Processing of biomass-burning aerosol in the eastern Mediterranean during summertime, Atmos. Chem. Phys., 14, 4793-4807, https://doi.org/10.5194/acp-14-4793-2014, 2014.

Bougiatioti, A., Nikolaou, P., Stavroulas, I., Kouvarakis, G., Weber, R., Nenes, A., Kanakidou, M., and Mihalopoulos, N.: Particle water and $\mathrm{pH}$ in the eastern Mediterranean: source variability and implications for nutrient availability, Atmos. Chem. Phys., 16, 4579-4591, https://doi.org/10.5194/acp-16-4579-2016, 2016.

Brown, S. G., Eberly, S., Paatero, P., and Norris, G. A.: Methods for estimating uncertainty in PMF solutions: Examples with ambient air and water quality data and guidance on reporting PMF results, Sci. Total Environ., 518-519, 626-635, 2015.

Canha, N., Almeida, S. M., Freitas, M. D. C., Wolterbeek, H. T., Cardoso, J., Pio, C., and Caseiro, A.: Impact of wood burning on indoor $\mathrm{PM}_{2.5}$ in a primary school in rural Portugal, Atmos. Environ., 94, 663-670, 2014.

Cavalli, F., Viana, M., Yttri, K. E., Genberg, J., and Putaud, J.-P.: Toward a standardised thermal-optical protocol for measuring atmospheric organic and elemental carbon: the EUSAAR protocol, Atmos. Meas. Tech., 3, 79-89, https://doi.org/10.5194/amt-3-792010, 2010.

Cesari, D., De Benedetto, G. E., Bonasoni, P., Busetto, M., Dinoi, A., Merico, E., Chirizzi, D., Cristofanelli, P., Donateo, A., Grasso, F. M., Marinoni, A., Pennetta, A., and Contini, D.: Sea- 
sonal variability of $\mathrm{PM}_{2.5}$ and $\mathrm{PM}_{10}$ composition and sources in an urban background site in Southern Italy, Sci. Total Environ., 612, 202-213, 2018.

Dall'Osto, M., Hellebust, S., Healy, R. M., Connor, I. P., Kourtchev, I., Sodeau, J. R., Ovadnevaite, J., Ceburnis, D., O’Dowd, C. D., and Wenger, J. C.: Apportionment of urban aerosol sources in Cork (Ireland) by synergistic measurement techniques, Sci. Total Environ., 493, 197-208, 2014.

Daskalakis, N., Tsigaridis, K., Myriokefalitakis, S., Fanourgakis, G. S., and Kanakidou, M.: Large gain in air quality compared to an alternative anthropogenic emissions scenario, Atmos. Chem. Phys., 16, 9771-9784, https://doi.org/10.5194/acp16-9771-2016, 2016.

Diapouli, E., Manousakas, M., Vratolis, S., Vasilatou, V., Maggos, Th., Saraga, D., Grigoratos, Th., Argyropoulos, G., Voutsa, D., Samara, C., and Eleftheriadis, K.: Evolution of air pollution source contributions over one decade, derived by $\mathrm{PM}_{10}$ and $\mathrm{PM}_{2.5}$ source apportionment in two metropolitan urban areas in Greece, Atmos. Environ., 164, 416-430, 2017.

Dockery, D. W. and Pope, C. A.: Acute respiratory effects of particulate air pollution, Annu. Rev. Public Health, 15, 107-132, 1994.

Drinovec, L., Mocnik, G., Zotter, P., Prévôt, A. S. H., Ruckstuhl, C., Coz, E., Rupakheti, M., Sciare, J., Müller, T., Wiedensohler, A., and Hansen, A. D. A.: The "dual-spot" Aethalometer: an improved measurement of aerosol black carbon with realtime loading compensation, Atmos. Meas. Tech., 8, 1965-1979, https://doi.org/10.5194/amt-8-1965-2015, 2015.

EEA: Status of black carbon monitoring in ambient air in Europe, Technical report no. 18/2013, https://doi.org/10.2800/10150, 2013.

EEA: Air quality in Europe - 2014 report, Technical report No. 5/2014, https://doi.org/10.2800/22775, 2014.

Fameli, K. M. and Assimakopoulos, V. D.: The new open Flexible Emission Inventory for Greece and the Greater Athens Area (FEI-GREGAA): Account of pollutant sources and their importance from 2006 to 2012, Atmos. Environ., 137, 17-37, 2016.

Fine, P. M., Cass, G. R., and Simoneit, B. R. T.: Chemical characterization of fine particle emissions from the fireplace combustion of woods grown in the southern United States, Environ. Sci. Technol., 36, 1442-1451, 2002.

Florou, K., Papanastasiou, D. K., Pikridas, M., Kaltsonoudis, C., Louvaris, E., Gkatzelis, G. I., Patoulias, D., Mihalopoulos, N., and Pandis, S. N.: The contribution of wood burning and other pollution sources to wintertime organic aerosol levels in two Greek cities, Atmos. Chem. Phys., 17, 3145-3163, https://doi.org/10.5194/acp-17-3145-2017, 2017.

Formenti, P., Elbert, W., Maenhaut, W., Haywood, J., and Andreae, M. O.: Chemical composition of mineral dust aerosol during the Saharan Dust Experiment (SHADE) airborne campaign in the Cape Verde region, September 2000, J. Geophys. Res., 108, 8576, https://doi.org/10.1029/2002JD002648, 2003.

Fourtziou, L., Liakakou, E., Stavroulas, I., Theodosi, C., Zarbas, P., Psiloglou, B., Sciare, J., Maggos, T., Bairachtari, K., Bougiatioti, A., Gerasopoulos, E., Sarda, R., Bonnaire, N., and Mihalopoulos, N.: Multi-tracer approach to characterize domestic wood burning in Athens (Greece) during wintertime, Atmos. Environ., 148, 89$101,2017$.

Gratsea, M., Liakakou, E., Mihalopoulos, N., Adamopoulos, A., Tsilibari, E., and Gerasopoulos, E.: The combined effect of re- duced fossil fuel consumption and increasing biomass combustion on Athens' air quality, as inferred from long term CO measurements, Sci. Total Environ., 592, 115-123, 2017.

Grivas, G., Cheristanidis, S., and Chaloulakou, A.: Elemental and organic carbon in the urban environment of Athens. Seasonal and diurnal variations and estimates of secondary organic carbon, Sci. Total Environ., 414, 535-545, 2012.

Grivas, G., Cheristanidis, S., Chaloulakou, A., Koutrakis, P., and Mihalopoulos, N.: Elemental composition and source apportionment of fine and coarse particles at traffic and urban background locations in Athens, Greece, Aerosol Air Qual. Res., 18, 1642$1659,2018$.

Guo, H., Sullivan, A. P., Campuzano-Jost, P., Schroder, J. C., LopezHilfiker, F. D., Dibb, J. E., Jimenez, J. L., Thornton, J. A., Brown, S. S., Nenes, A., and Weber, R. J.: Fine particle $\mathrm{pH}$ and the partitioning of nitric acid during winter in the northeastern United States, J. Geophys. Res., 121, 10355-10376, 2016.

Harrison, R. M. and Pio, C. A.: Size-differentiated composition of inorganic atmospheric aerosols of both marine and polluted continental origin, Atmos. Environ., 17, 1733-1738, 1983.

Hasheminassab, S., Daher, N., Saffari, A., Wang, D., Ostro, B. D., and Sioutas, C.: Spatial and temporal variability of sources of ambient fine particulate matter $\left(\mathrm{PM}_{2.5}\right)$ in California, Atmos. Chem. Phys., 14, 12085-12097, https://doi.org/10.5194/acp-1412085-2014, 2014.

Ho, K. F., Lee, S. C., Cao, J. J., Chow, J. C., Watson, J. G., and Chan, C. K.: Seasonal variations and mass closure analysis of particulate matter in Hong Kong, Sci. Total Environ., 355, 276287, 2006.

Kalogridis, A.-C., Vratolis, S., Liakakou, E., Gerasopoulos, E., Mihalopoulos, N., and Eleftheriadis, K.: Assessment of wood burning versus fossil fuel contribution to wintertime black carbon and carbon monoxide concentrations in Athens, Greece, Atmos. Chem. Phys., 18, 10219-10236, https://doi.org/10.5194/acp-1810219-2018, 2018.

Karageorgos, E. T. and Rapsomanikis, S.: Chemical characterization of the inorganic fraction of aerosols and mechanisms of the neutralization of atmospheric acidity in Athens, Greece, Atmos. Chem. Phys., 7, 3015-3033, https://doi.org/10.5194/acp-7-30152007, 2007.

Karageorgos, E. T. and Rapsomanikis, S.: Assessment of the sources of the inorganic fraction of aerosol in a conurbation, Int. J. Environ. An., 90, 64-83, 2010.

Karanasiou, A. A., Siskos, P. A., and Eleftheriadis, K.: Assessment of source apportionment by positive matrix factorization analysis on fine and coarse urban aerosol size fractions, Atmos. Environ., 43, 3385-3395, 2009.

Kassomenos, P., Vardoulakis, S., Chaloulakou, A., Grivas, G., Borge, R., and Lumbreras, J: Levels, sources and seasonality of coarse particles $\left(\mathrm{PM}_{10}-\mathrm{PM}_{2.5}\right)$ in three European capitals - Implications for particulate pollution control, Atmos. Environ., 54, 337-347, 2012.

Kassomenos, P. A., Vardoulakis, S., Chaloulakou, A., Paschalidou, A. K., Grivas, G., Borge, R., and Lumbreras, J.: Study of $\mathrm{PM}_{10}$ and $\mathrm{PM}_{2.5}$ levels in three European cities: Analysis of intra and inter urban variations, Atmos. Environ., 87, 153-163, 2014.

Kawamura, K. and Ikushima, K.: Seasonal changes in the distribution of dicarboxylic acids in the urban atmosphere, Environ. Sci. Technol., 27, 2227-2235, 1993. 
Kawamura, K., Kasukabe, H., and Barrie, L. A.: Source and reaction pathways of dicarboxylic acids, ketoacids and dicarbonyls in arctic aerosols: One year of observations, Atmos. Environ., 30, 1709-1722, 1996.

Khalil, M. A. K. and Rasmussen, R. A.: Tracers of wood smoke, Atmos. Environ., 37, 1211-1222, 2003.

Koçak, M., Theodosi, C., Zarmpas, P., Im, U., Bougiatioti, A., Yenigun, O., and Mihalopoulos, N.: Particulate matter $\left(\mathrm{PM}_{10}\right)$ in Istanbul: Origin, source areas and potential impact on surrounding regions, Atmos. Environ., 45, 6891-6900, 2011.

Koulouri, E., Saarikoski, S., Theodosi, C., Markaki, Z., Gerasopoulos, E., Kouvarakis, G., Makela, T., Hillamo, R., and Mihalopoulos, N.: Chemical composition and sources of fine and coarse aerosol particles in the Eastern Mediterranean, Atmos. Environ., 42, 6542-6550, 2008.

Krall, J. R., Anderson, G. B., Dominici, F., Bell, M. L., and Peng, R. D.: Short-term exposure to particulate matter constituents and mortality in a national study of U.S. urban communities, Environ. Health Persp., 121, 1148-1153, 2013.

Li, N., Sioutas, C., Cho, A., Schmitz, D., Misra, C., Sempf, J., Wang, M., Oberley, T., Froines, J., and Nel, A.: Ultrafine particulate pollutants induce oxidative stress and mitochondrial damage, Environ. Health Persp., 111, 455-460, 2003.

Li, Z., Hopke, P. K., Husain, L., Qureshi, S., Dutkiewicz, V. A., Schwab, J. J., Drewnick, F., and Demerjian, K. L.: Sources of fine particle composition in New York city, Atmos. Environ., 38, 6521-6529, 2004.

Lipsett, M. J., Ostro, B. D., Reynolds, P., Goldberg, D., Hertz, A., Jerrett, M., Smith, D. F., Garcia, C., Chang, E. T., and Bernstein, L.: Long-term exposure to air pollution and cardiorespiratory disease in the California teachers study cohort, Am. J. Resp. Crit. Care, 184, 828-835, 2011.

Maenhaut, W., Vermeylen, R., Claeys, M., Vercauteren, J., and Roekens, E.: Sources of the $\mathrm{PM}_{10}$ aerosol in Flanders, Belgium, and re-assessment of the contribution from wood burning, Sci. Total Environ., 562, 550-560, 2016.

Manalis, N., Grivas, G., Protonotarios, V., Moutsatsou, A., Samara, C., and Chaloulakou, A.: Toxic metal content of particulate matter $\left(\mathrm{PM}_{10}\right)$, within the Greater Area of Athens, Chemosphere, 60 , 557-566, 2005.

Mantas, E., Remoundaki, E., Halari, I., Kassomenos, P., Theodosi, C., Hatzikioseyian, A., and Mihalopoulos, N.: Mass closure and source apportionment of $\mathrm{PM}_{2.5}$ by positive matrix factorization analysis in urban Mediterranean environment, Atmos. Environ., 94, 154-163, 2014.

Mariani, R. L. and de Mello, W. Z.: $\mathrm{PM}_{2.5-10}, \mathrm{PM}_{2.5}$ and associated water-soluble inorganic species at a coastal urban site in the metropolitan region of Rio de Janeiro, Atmos. Environ., 41, 2887-2892, 2007.

Mihalopoulos, N., Stephanou, E., Kanakidou, M., Pilitsidis, S., and Bousquet, P.: Tropospheric aerosol ionic composition in the Eastern Mediterranean region, Tellus B, 49, 314-326, 1997.

Myriokefalitakis, S., Tsigaridis, K., Mihalopoulos, N., Sciare, J., Nenes, A., Kawamura, K., Segers, A., and Kanakidou, M.: In-cloud oxalate formation in the global troposphere: a 3-D modeling study, Atmos. Chem. Phys., 11, 5761-5782, https://doi.org/10.5194/acp-11-5761-2011, 2011.

Nava, S., Lucarelli, F., Amato, F., Becagli, S., Calzolai, G., Chiari, M., Giannoni, G., Traversi, R., and Udisti, R.: Biomass burn- ing contributions estimated by synergistic coupling of daily and hourly aerosol composition records, Sci. Total Environ., 511, 1120, 2015.

Ohta, S. and Okita, T.: A chemical characterization of atmospheric aerosol in Sapporo, Atmos. Environ., A-Gen., 24, 815-822, 1990.

Ostro, B., Broadwin, R., Green, S., Feng, W. Y., and Lipsett, M.: Fine particulate air pollution and mortality in nine California counties: results from CALFINE, Environ. Health Persp., 114, 29-33, 2006.

Ostro, B., Lipsett, M., Reynolds, P., Goldberg, D., Hertz, A., Garcia, C., Henderson, K. D., and Bernstein, L.: Long-term exposure to constituents of fine particulate air pollution and mortality: results from the California Teachers Study, Environ Health Persp., 118, 363-369, https://doi.org/10.1289/ehp.0901181, 2010.

Paatero, P., Eberly, S., Brown, S. G., and Norris, G. A.: Methods for estimating uncertainty in factor analytic solutions, Atmos. Meas. Tech., 7, 781-797, https://doi.org/10.5194/amt-7781-2014, 2014.

Pachon, J. E., Weber, R. J., Zhang, X., Mulholland, J. A., and Russell, A. G.: Revising the use of potassium $(\mathrm{K})$ in the source apportionment of $\mathrm{PM}_{2.5}$, Atmos. Pollut. Res., 4, 14-21, 2013.

Pakkanen, T. A., Loukkola, K., Korhonen, C. H., Aurela, M., Mäkelä, T., Hillamo, R. E., Aarnio, P., Koskentalo, T., Kousa, A., and Maenhaut, W.: Sources and chemical composition of atmospheric fine and coarse particles in the Helsinki area, Atmos. Environ., 35, 5381-5391, 2001.

Pandolfi, M., Gonzalez-Castanedo, Y., Alastuey, A., de la Rosa, J. D., Mantilla, E., Sanchez de la Campa, A., Querol, X., Pey, J., Amato, F., and Moreno, T.: Source apportionment of $\mathrm{PM}_{10}$ and $\mathrm{PM}_{2.5}$ at multiple sites in the strait of Gibraltar by PMF: impact of shipping emissions, Environ. Sci. Pollut. R., 18, 260-269, 2011.

Paraskevopoulou, D., Liakakou, E., Gerasopoulos, E., Theodosi, C., and Mihalopoulos, N.: Long-term characterization of organic and elemental carbon in the $\mathrm{PM}_{2.5}$ fraction: the case of Athens, Greece, Atmos. Chem. Phys., 14, 13313-13325, https://doi.org/10.5194/acp-14-13313-2014, 2014.

Paraskevopoulou, D., Liakakou, E., Gerasopoulos, E., and Mihalopoulos, N.: Sources of atmospheric aerosol from long-term measurements (5 years) of chemical composition in Athens, Greece, Sci. Total Environ., 527-528, 165-178, 2015.

Park, S. S., Ondov, J. M., Harrison, D., and Naire, N. P.: Seasonal and shorter-term variations in particulate atmospheric nitrate in Baltimore, Atmos. Environ., 39, 2011-2020, 2005.

Pateraki, S., Assimakopoulos, V. D., Bougiatioti, A., Kouvarakis, G., Mihalopoulos, N., and Vasilakos, C.: Carbonaceous and ionic compositional patterns of fine particles over an urban Mediterranean area, Sci. Total Environ., 424, 251-263, 2012.

Pérez, N., Pey, J., Reche, C., Cortés, J., Alastuey, A., and Querol, $\mathrm{X}$.: Impact of harbour emissions on ambient $\mathrm{PM}_{10}$ and $\mathrm{PM}_{2.5}$ in Barcelona (Spain): Evidences of secondary aerosol formation within the urban area, Sci. Total Environ., 571, 237-250, 2016.

Pey, J., Perez, N., Castillo, S., Viana, M., Moreno, T., Pandolfi, M., Lopez-Sebastian, J. M., Alastuey, A., and Querol, X.: Geochemistry of regional background aerosols in the Western Mediterranean, Atmos. Res., 94, 422-435, 2009.

Pio, C. A., Legrand, M., Oliveira, T., Afonso, J., Santos, C., Caseiro, A., Fialho, P., Barata, F., Puxbaum, H., Sanchez- 
Ochoa, A., Kasper-Giebl, A., Gelencsér, A., Preunkert, S., and Schock, M.: Climatology of aerosol composition (organic versus inorganic) at non-urban areas on a West-East transect across Europe, J. Geophys. Res., 112, D23S02, https://doi.org/10.1029/2006JD008038, 2007.

Pio, C., Cerqueira, M., Harrison, R. M., Nunes, T., Mirante, F., Alves, C., Oliveira, C., Sanchez de la Campa, A., Artíñano, B., and Matos, M.: OC/EC ratio observations in Europe: Re-thinking the approach for apportionment between primary and secondary organic carbon, Atmos. Environ., 45, 6121-6132, 2011.

Pope III, C. A., Burnett, R. T., Thun, M. J., Calle, E. E., Krewski, D., and Ito, K.: Lung cancer, cardiopulmonary mortality, and longterm exposure to fine particulate air pollution, J. Am. Med. Assoc., 287, 1132-1141, 2002.

Putaud, J. P., Van Dingenen, R., Alastuey, A., Bauer, H., Birmili, W., Cyrys, J., Flentje, H., Fuzzi, S., Gehrig, R., Hansson, H. C., Harrison, R. M., Herrmann, H., Hitzenberger, R., Huglin, C., Jones, A. M., Kasper-Giebl, A., Kiss, G., Kousa, A., Kuhlbusch, T. A. J., Loschau, G., Maenhaut, W., Molnar, A., Moreno, T., Pekkanen, J., Perrino, C., Pitz, M., Puxbaum, H., Querol, X., Rodriguez, S., Salma, I., Schwarz, J., Smolik, J., Schneider, J., Spindler, G., ten Brink, H., Tursic, J., Viana, M., Wiedensohler, A., and Raes, F.: A European aerosol phenomenology 3: Physical and chemical characteristics of particulate matter from 60 rural, urban, and kerbside sites across Europe, Atmos. Environ., 44, 1308-1320, 2010.

Querol, X., Alastuey, A., Ruiz, C. R., Artinano, B., Hansson, H. C., Harrison, R. M., Buringh, E., ten Brink, H. M., Lutz, M., Bruckmann, P., Straehl, P., and Schneider, J.: Speciation and origin of $\mathrm{PM}_{10}$ and $\mathrm{PM}_{2.5}$ in selected European cities, Atmos. Environ., 38, 6547-6555, 2004.

Querol, X., Alastuey, A., Pey, J., Cusack, M., Pérez, N., Mihalopoulos, N., Theodosi, C., Gerasopoulos, E., Kubilay, N., and Koçak, M.: Variability in regional background aerosols within the Mediterranean, Atmos. Chem. Phys., 9, 4575-4591, https://doi.org/10.5194/acp-9-4575-2009, 2009.

Reche, C., Viana, M., Amato, F., Alastuey, A., Moreno, T., Hillamo, R., Teinilä, K., Saarnio, K., Seco, R., Peñuelas, J., Mohr, C., Prévôt, A. S. H., and Querol, X.: Biomass burning contributions to urban aerosols in a coastal Mediterranean City, Sci. Total Environ., 427-428, 175-190, 2012.

Reff, A., Eberly, S. I., and Bhave, P. V.: Receptor modeling of ambient particulate matter data using positive matrix factorization: Review of existing methods, J. Air Waste Ma., 57, 146-154, 2007.

Remoundaki, E., Kassomenos, P., Mantas, E., Mihalopoulos, N., and Tsezos, M.: Composition and mass closure of $\mathrm{PM}_{2.5}$ in urban environment (Athens, Greece), Aerosol Air Qual. Res., 13, 72-82, 2013.

Saffari, A., Daher, N., Samara, C., Voutsa, D., Kouras, A., Manoli, E., Karagkiozidou, O., Vlachokostas, C., Moussiopoulos, N., Shafer, M., Schauer, J., and Sioutas, C.: Increased biomass burning due to economic crisis in Greece and its adverse impact on wintertime air quality in Thessaloniki, Environ. Sci. Technol., 47, 13313-13320, 2013.

Salma, I., Balásházy, I., Winkler-Heil, R., Hofmann, W., and Záray, G.: Effect of particle mass size distribution on the deposition of aerosols in the human respiratory system, J. Aerosol Sci., 33, 119-132, 2002.
Salvador, P., Artíñano, B., Querol, X., Alastuey, A., and Costoya, M.: Characterisation of local and external contributions of atmospheric particulate matter at a background coastal site, Atmos. Environ., 41, 1-17, 2007.

Sandradewi, J., Prévôt, A. S. H., Weingartner, E., Schmidhauser, R., Gysel, M., and Baltensperger, U.: A study of wood burning and traffic aerosols in an Alpine valley using a multi-wavelength Aethalometer, Atmos. Environ., 42, 101-112, 2008.

Scheff, P. A. and Valiozis, C.: Characterization and source identification of respirable particulate matter in Athens, Greece, Atmos. Environ., 24, 203-211, 1990.

Sciare, J., Oikonomou, K., Cachier, H., Mihalopoulos, N., Andreae, M. O., Maenhaut, W., and Sarda-Estève, R.: Aerosol mass closure and reconstruction of the light scattering coefficient over the Eastern Mediterranean Sea during the MINOS campaign, Atmos. Chem. Phys., 5, 2253-2265, https://doi.org/10.5194/acp-5-22532005, 2005.

Seinfeld, J. H. and Pandis, S. N.: Atmospheric Chemistry and Physics: From Air Pollution to Climate Change, John Wiley, New York, 1998.

Sillanpää, M., Frey, A., Hillamo, R., Pennanen, A. S., and Salonen, R. O.: Organic, elemental and inorganic carbon in particulate matter of six urban environments in Europe, Atmos. Chem. Phys., 5, 2869-2879, https://doi.org/10.5194/acp-5-2869-2005, 2005.

Sillanpää, M., Hillamo, R., Saarikoski, S., Frey, A., Pennanen, A., Makkonen, U., Spolnik, Z., Van Grieken, R., Braniš, M., Brunekreef, B., Chalbot, M. C., Kuhlbusch, T., Sunyer, J., Kerminen, V. M., Kulmala, M., and Salonen, R. O.: Chemical composition and mass closure of particulate matter at six urban sites in Europe, Atmos. Environ., 40, 212-223, 2006.

Siskos, P. A., Bakeas, E. B., Lioli, I., Smirnioudi, V. N., and Koutrakis, P.: Chemical characterization of $\mathrm{PM}_{2.5}$ aerosols in Athens-Greece, Environ. Technol., 22, 687-695, 2001.

Squizzato, S., Masiol, M., Agostini, C., Visin, F., Formenton, G., Harrison, R. M., and Rampazzo, G.: Factors, origin and sources affecting $\mathrm{PM}_{1}$ concentrations and composition at an urban background site, Atmos. Res., 180, 262-273, 2016.

Stavroulas, I., Bougiatioti, A., Paraskevopoulou, D., Grivas, G., Liakakou, E., Gerasopoulos, E., and Mihalopoulos, N.: Sources and processes that control the submicron organic aerosol in an urban Mediterranean environment (Athens) using high temporal resolution chemical composition measurements, Atmos. Chem. Phys. Discuss., https://doi.org/10.5194/acp-2018-356, in review, 2018.

Stiebet, D. M., Judek, S., and Burnett, R. T.: Meta-analysis of timeseries studies of air pollution and mortality: effects of gases and particles and the influence of cause of death, age, and season, J. Air Waste Ma., 52, 470-484, 2002.

Tan, J., Duan, J., Zhen, N., He, K., and Hao, J.: Chemical characteristics and source of size-fractionated atmospheric particle in haze episode in Beijing, Atmos. Res., 167, 24-33, 2016.

Theodosi, C., Im, U., Bougiatioti, A., Zarmpas, P., Yenigun, O., and Mihalopoulos, N.: Aerosol chemical composition over Istanbul, Sci. Total Environ., 408, 2482-2491, 2010a.

Theodosi, C., Markaki, Z., Tselepides A., and Mihalopoulos, N.: The significance of atmospheric inputs of soluble and particulate major and trace metals to the Eastern Mediterranean Sea, Mar. Chem., 120, 154-163, 2010 b. 
Theodosi, C., Grivas, G., Zarmpas, P., Chaloulakou, A., and Mihalopoulos, N.: Mass and chemical composition of sizesegregated aerosols $\left(\mathrm{PM}_{1}, \mathrm{PM}_{2.5}, \mathrm{PM}_{10}\right)$ over Athens, Greece: local versus regional sources, Atmos. Chem. Phys., 11, 1189511911, https://doi.org/10.5194/acp-11-11895-2011, 2011.

Uria-Tellaetxe, I. and Carslaw, D. C.: Conditional bivariate probability function for source identification, Environ. Modell. Softw., 59, 1-9, 2014.

Valaoras, G., Huntzicker, J. J., and White, W. H.: On the contribution of motor vehicles to the Athenian "nephos". An application of factor signatures, Atmos. Environ., 22, 965-971, 1988.

Viana, M., Querol, X., Ballester, F., Llop, S., Esplugues, A., Fernández Patier, R., García Dos Santos, S., and Herce, M. D.: Characterising exposure to PM aerosols for an epidemiological study, Atmos. Environ., 42, 1552-1568, 2008.

Viana, M., Reche, C., Amato, F., Alastuey, A., Querol, X., Moreno, T., Lucarelli, F., Nava, S., Calzolai, G., Chiari, M., and Rico, M.: Evidence of biomass burning aerosols in the Barcelona urban environment during winter time, Atmos. Environ., 72, 81-88, 2013.

Vrekoussis, M., Richter, A., Hilboll, A., Burrows, J. P., Gerasopoulos, E., Lelieveld, J., Barrie, L., Zerefos, C., and Mihalopoulos, N.: Economic crisis detected from space: air quality observations over Athens/Greece, Geophys. Res. Lett., 40, 458-463, 2013.
Weckwerth, G.: Verification of traffic emitted aerosol components in the ambient air of Cologne, Germany, Atmos. Environ., 35, 5525-5536, 2001.

Wedepohl, K. H.: The composition of the continental crust, Geochem. Cosmochim. Ac., 59, 1217-1232, 1995

Xie, S. D., Liu, Z., Chen, T., and Hua, L.: Spatiotemporal variations of ambient $\mathrm{PM}_{10}$ source contributions in Beijing in 2004 using positive matrix factorization, Atmos. Chem. Phys., 8, 27012716, https://doi.org/10.5194/acp-8-2701-2008, 2008.

Yao, X., Lau, A. P. S., Fang, M., Chan, C. K., and Hu, M.: Size distributions and formation of ionic species in atmospheric particulate pollutants in Beijing, China: 2-dicarboxylic acids, Atmos. Environ. 37, 3001-3007, 2003.

Yu, J. Z., Huang, X. F., Xu, J., and Hu, M.: When aerosol sulfate goes up, so does oxalate: Implication for the formation mechanisms of oxalate, Environ. Sci. Technol., 39, 128-133, 2005.

Yubero, E., Carratalá, A., Crespo, J., Nicolás, J., Santacatalina, M., Nava, S., Lucarelli, F., and Chiari, M.: $\mathrm{PM}_{10}$ source apportionment in the surroundings of the San Vicente del Raspeig cement plant complex in southeastern Spain, Environ. Sci. Pollut. R., 18, 64-74, 2011. 